\title{
Aggression and anxiety: social context and neurobiological links
}

\author{
Inga D. Neumann ${ }^{*}$, Alexa H. Veenema ${ }^{1,2}$ and Daniela I. Beiderbeck ${ }^{1}$ \\ ' Department of Behavioural and Molecular Neuroendocrinology, University of Regensburg, Regensburg, Germany \\ 2 Department of Psychology, Center for Neuroendocrine Studies, University of Massachusetts Amherst, Amherst, MA, USA
}

Edited by:

Andreas Meyer-Lindenberg,

Central Institute of Mental Health,

Germany

Reviewed by:

Geert De Vries,

University of Massachusetts Amherst,

USA

Barbara Vollmayr,

University of Heidelberg, Germany

Miriam Schneider

Central Institute of Mental Health,

Germany

*Correspondence

Inga D. Neumann,

Department of Behavioural and

Molecular Neuroendocrinology

University of Regensburg,

Universitaetsstrasse 31, 93053

Regensburg, Germany.

e-mail: inga.neumann@biologie.

uni-regensburg.de
Psychopathologies such as anxiety- and depression-related disorders are often characterized by impaired social behaviours including excessive aggression and violence. Excessive aggression and violence likely develop as a consequence of generally disturbed emotional regulation, such as abnormally high or low levels of anxiety. This suggests an overlap between brain circuitries and neurochemical systems regulating aggression and anxiety. In this review, we will discuss different forms of male aggression, rodent models of excessive aggression, and neurobiological mechanisms underlying male aggression in the context of anxiety. We will summarize our attempts to establish an animal model of high and abnormal aggression using rats selected for high (HAB) vs. low ( $L A B$ ) anxiety-related behaviour. Briefly, male $L A B$ rats and, to a lesser extent, male HAB rats show high and abnormal forms of aggression compared with non-selected (NAB) rats, making them a suitable animal model for studying excessive aggression in the context of extremes in innate anxiety. In addition, we will discuss differences in the activity of the hypothalamic-pituitary-adrenal axis, brain arginine vasopressin, and the serotonin systems, among others, which contribute to the distinct behavioural phenotypes related to aggression and anxiety. Further investigation of the neurobiological systems in animals with distinct anxiety phenotypes might provide valuable information about the link between excessive aggression and disturbed emotional regulation, which is essential for understanding the social and emotional deficits that are characteristic of many human psychiatric disorders.

Keywords: abnormal aggression, vasopressin, serotonin, HPA axis, trait anxiety, HAB rats, LAB rats, violence

\section{INTRODUCTION}

Every year, more than 700,000 people worldwide die because of assault (Bartolomeos et al., 2007), and many more become victims of aggressive behaviour including domestic violence, terrorism, and hooliganism, or get physically or psychologically injured. Besides the suffering of the affected persons and their families, a large financial burden for the society emerges. Several psychiatric disorders like depression (Fava, 1998; Mammen et al., 2002), anxiety disorders, antisocial personality disorder (Eronen et al., 1998; Moran, 1999), post-traumatic stress disorder (PTSD; Beckham and Moore, 2000; Ohayon and Shapiro, 2000), borderline syndrome (Sanislow et al., 2000; Skodol et al., 2002), and alcohol abuse (Giancola et al., 2009) were associated not only with severe emotional disturbances, but also with impaired social functioning, like social withdrawal, impaired social cognition, and excessive aggression (for review see Kohn and Asnis, 2003; Swann, 2003). This is not surprising, given the fact that the neural circuits regulating emotions and social behaviours are highly interconnected. In fact, deficits in social behaviour leading to excessive aggression may develop as a consequence of disturbed emotional regulation (Davidson et al., 2000). Accordingly, a better understanding of the link between social behaviours and emotional regulation and their neurobiological underpinnings is essential to improve the treatment of many psychopathologies. In this review, we will discuss different forms of male aggression, rodent models of high and/or abnormal aggression, and neurobiological mechanisms underlying male aggression in the context of anxiety. In particular, we will focus on our own attempts to reveal a possible association between male aggression and innate anxiety using rats selectively bred for high (HAB) and low (LAB) anxiety-related behaviour.

Two main forms of human excessive/violent aggression are described, namely impulsive-reactive-hostile-affective aggression and controlled-proactive-instrumental-predatory aggression (Vitiello and Stoff, 1997). Whereas the first form of aggression is seen in patients with depression, PTSD, or intermittent explosive disorder, the second type of aggression can be revealed in patients with personality disorders (conduct, antisocial, and borderline disorder), but may also be found in individuals without noticeable emotional or social deficits (i.e. the "friendly neighbour" or the "polite and quiet young man"). In particular, cases of violent and criminal behaviour displayed by these "unlikely" individuals are difficult to understand and indicate the urgent necessity to reveal underlying neurobiological mechanisms of abnormal aggression in more detail. Both forms of excessive aggression are associated with distinct disturbances in the regulation of emotions and alterations in autonomic and neuroendocrine functioning. More specifically, impulsive-reactive-hostile-affective aggression is generally associated with high emotional reactions and autonomic responses including high glucocorticoid levels, whereas controlledproactive-instrumental-predatory aggression is generally associated with low emotional, autonomic, and glucocorticoid responses, and low skin conductance (summarized in Haller and Kruk, 2006). 
We hypothesize that the emotional responses underlying the two distinct forms of aggression are linked to differences in anxietymediating brain pathways.

\section{AGGRESSION AND ANXIETY}

Species-specific signals transmitting the emotional state of an individual are very prominent in humans and animals living in herds, cohorts, or any other kind of social community. The expression of emotions involving aggression and anxiety-related behaviours is essential for effective communication between individuals within a society.

\section{MALE AGGRESSION}

Male aggression is necessary for the acquisition and maintenance of nutrition, territory, and mating partners. Species-specific rules have to be strictly obeyed to guarantee effective and harmless communication. Thus, adaptive offensive aggression is comprised primarily of harmless threat behaviours allowing the opponent to escape or to switch to submissive behaviours in order to avoid direct physical confrontation. In rodents, such signs of offensive aggression include piloerection (intimidation of the opponent by larger appearance) and lateral threat (arched back and exposure of the flank). In case of an offensive attack, less vulnerable body parts of the opponent, such as those covered with muscles and a thick layer of skin, are targeted to avoid serious injuries (Blanchard and Blanchard, 1977; Blanchard et al., 2003). While offensive aggression is usually expressed during a fight for territory or exclusive mating, defensive aggression is mainly displayed in life-threatening situations and is linked to increased fear (Blanchard and Blanchard, 1981). As opposed to offensive aggression, defensive aggression is less or not signalled in advance, and attack targets include more vulnerable body parts (such as the head, belly, and genitals) (Blanchard and Blanchard, 1977; Blanchard et al., 2003).

\section{ABNORMAL AGGRESSION}

Although offensive aggression is adaptive and essential for reproductive success, it can become harmful and turn into abnormal forms of aggression when an individual (i) disregards species-specific rules, (ii) becomes insensitive towards social signals of the opponent (e.g. ignores submissiveness and continues attacking), or (iii) has a mismatched response to a provocation (Haller and Kruk, 2006). In many species, attacks directed by a male towards female conspecifics or towards vulnerable body parts of a male opponent in a non lifethreatening situation are considered to be abnormal (Haller et al., 2001). Although abnormal forms of aggression are rarely seen in animals living in their natural environment, several factors may increase the appearance of exaggerated forms of aggression such as housing under stressful conditions, acute exposure to stress, and genetic risk factors (see also the sections Acute Interventions, Transgenic Mice, Early Life Stress, Selective Breeding).

\section{THE RESIDENT-INTRUDER TEST: A TEST FOR MALE AGGRESSION}

The resident-intruder (RI) test has been designed and validated for rodents to study offensive male aggression under standardized laboratory conditions (Koolhaas et al., 1980). In preparation for the RI test, the experimental male rat is typically housed with a female for several days or weeks to stimulate territorial aggression
(Flannelly and Lore, 1977). The test is performed in the absence of the female in the early dark phase of the light/dark cycle, i.e. at a time of heightened activity. The resident male rat is confronted with a slightly smaller, unfamiliar male intruder mostly of the same strain, which is placed into the resident's home-cage. Multiple aggression-related parameters such as the latency to the first attack and the frequency and duration of aggressive behaviours displayed by the resident as well as defensive or exploratory behaviour of the intruder can be quantified.

\section{ANXIETY-RELATED BEHAVIOUR}

Anxiety may be interpreted as an emotional anticipation of an aversive situation and is reflected by species-specific behavioural fear responses to stressful and threatening stimuli characteristic for individual trait anxiety. Fear is not seen as basal state (as is anxiety), but as a complex behavioural response, such as startle or freezing. Further, in addition to factors which determine innate (trait) anxiety, several environmental or pharmacological factors may interact with the genetic background and determine the individual level of state anxiety and the final behavioural phenotype. Emotionality, often used as synonym for anxiety as well as fearfulness, may be seen in a broader sense, comprising both trait and state anxiety and stimulus-related fear. Emotionality is one of the major components underlying the ability of an organism to assess stressful stimuli and scenarios, and to adequately cope with them.

Although adequate levels of trait anxiety and subsequent fear responses are beneficial for an individual, exaggerated and uncontrolled forms of anxiety and fear are maladaptive in both animals and humans. The lifetime prevalence of anxiety disorders, like panic disorder or general anxiety disorder, is about $17 \%$ (Somers et al., 2006) with social anxiety disorder, like social phobia, being the most common one (Kessler et al., 1994). A variety of rodent models has been established in order to reveal the complex brain circuitries, and neuronal and genetic mechanisms underlying normal and extreme forms of trait or state anxiety (Gordon and Hen, 2004; Bourin et al., 2007). Such rodent models include selective breeding of rats or mice to augment naturally occurring differences in anxiety (Landgraf and Wigger, 2002; Bunck et al., 2009), exposure to early life stress (Wigger and Neumann, 1999; Huot et al., 2001), or to chronic stress in adulthood (Barrot et al., 2005; Reber et al., 2007), transgenic modification (Bale et al., 2000; Mantella et al., 2003; Müller et al., 2003), and acute interventions that alter state anxiety (Neumann et al., 2000; Millan, 2003; Slattery and Neumann, 2010). In this review, we will mainly focus on our model of genetic selection for differences in trait anxiety, i.e. on HAB and $\mathrm{LAB}$ rats.

For the quantification of anxiety-related behaviour in rodents several laboratory tests have been successfully validated (for review see File et al., 2004). The black-white box or the elevated plus-maze (EPM), for example, are the most frequently used non-conditioned tests for anxiety based on the conflict between the rat's exploratory drive and its innate fear of bright and open spaces (Crawley and Goodwin, 1980). A high level of anxiety is expressed by avoidance of these aversive zones, i.e. the open, bright or unprotected compartments/arms of the test apparatus, which can be validated with established anxiolytic as well as anxiogenic substances (Pellow et al., 1985). 


\section{LINK BETWEEN AGGRESSION AND ANXIETY}

Findings from both preclinical and clinical studies concerning the link between anxiety and aggression are conflicting, as anxiolytic drugs, for example, can reduce or potentiate male aggressive behaviour in several species including rodents (Malick, 1978; Wongwitdecha and Marsden, 1996; Kudryavtseva and Bondar, 2002; Haller et al., 2007). Besides their anxiolytic, tranquilizing and sedative effects, benzodiazepines generally reduce aggressive behaviour in humans, although, they may induce aggression in certain patients suffering from panic or conduct disorders (DiMascio, 1973; Bond et al., 1995; Cherek and Lane, 2001). Other drugs used for the treatment of aggression-related disorders exert their effects via the dopaminergic or the serotonergic systems, which are both known to affect anxiety (Millan, 2003; de Almeida et al., 2005). Thus, although co-regulation of aggression and anxiety is likely based on the involvement of overlapping brain pathways, their complex interplay is far from being clear due to the limited availability of relevant animal models combining aggression and anxiety.

\section{RODENT MODELS OF AGGRESSION: LINK TO ANXIETY}

Animal models are essential for revealing neurobiological mechanisms of complex behaviours like anxiety, depression, and aggression and their associated psychopathologies. Due to the tendency towards an increase in excessive aggression and violence in industrialized societies, there is an urgent need to understand these abnormal forms of social behaviour in more detail and, subsequently, to develop more efficient therapeutic strategies. Despite a high need, and in contrast to rodent models of anxiety and depression, it is remarkable that the number of rodent models of aggression in combination with anxiety is extremely limited. Here, we briefly describe potential rodent models characterized by alterations in both aggression and anxiety-related behaviours.

\section{ACUTE INTERVENTIONS}

Several acute manipulations have been established to induce a state of hyper-aggression or abnormal aggression, such as frustration (deprivation of an expected reward), instigation (pre-exposure to a possible opponent), alcohol (Miczek et al., 2003; de Almeida et al., 2005), glucocorticoid-deficiency (Haller et al., 2001), and acute pharmacological approaches (de Almeida et al., 2005; Ferris et al., 2006). In some of these models, both aggression and anxietyrelated behaviour were altered, making these acute models suitable for further detailed investigation into the link between aggression and anxiety.

\section{TRANSGENIC MICE}

Our understanding of the impact of genetic factors shaping aggression has been significantly improved by the use of transgenic animal models. Reduced offensive aggression has been found in male knockout mice lacking the long form of the dopamine D2 receptor (Vukhac et al., 2001), the $\alpha$-isoform of the oestrogen receptor (Ogawa et al., 1997; Scordalakes and Rissman, 2003), the arginine vasopressin (AVP) V1b receptor (Wersinger et al., 2002), or the enzyme dopamine $\beta$-hydroxylase (Marino et al., 2005). In contrast, elevated offensive aggression is seen in mice lacking serotonin (5-HT) 1B receptors (Saudou et al., 1994), dopamine transporters (Rodriguiz et al., 2004), nitric oxide synthase (Nelson et al.,
1995), or monoamine oxidase A (Cases et al., 1995). Interestingly, in most of these transgenic animals, concurrent alterations in anxiety and/or stress responsiveness were found, indicating a link between anxiety and aggressive responses. For example, mice lacking the regulators of $\mathrm{G}$ protein signalling 2 show a low level of aggression and a high level of anxiety (Oliveira-Dos-Santos et al., 2000). In contrast, the elevated levels of aggression found in monoamine oxidase A knockout mice is accompanied by a lower level of anxietyrelated behaviour (Cases et al., 1995). Enkephalin knockout mice (König et al., 1996) and $\alpha$-calcium-calmodulin kinase II knockout mice (Chen et al., 1994) show an increase in both aggression and anxiety/fear, whereas male oxytocin knockout mice have low levels of both aggression and anxiety (DeVries et al., 1997; Winslow et al., 2000). However, there are a few studies suggesting that anxiety and aggression can be altered independently. For example, male mice lacking the AVP V1b receptor are less aggressive than wild-type mice without a change in anxiety-related behaviour (Wersinger et al., 2002).

\section{EARLY LIFE STRESS}

Early life stress (e.g. emotional neglect, loss of parents, child abuse) is a major risk factor for the development of anxiety disorders and depression as well as excessive aggression and violence in adulthood (Dodge et al., 1990; Loeber and Stouthamer-Loeber, 1998; Heim and Nemeroff, 2001; Barnow and Freyberger, 2003). This has been confirmed by several rodent models of early life stress, including prenatal and postnatal stress, which have been - in the first instance - developed for studying neurobiological mechanisms of anxiety- and depression-related disorders (Levine et al., 1991; Suchecki and Palermo Neto, 1991; Plotsky and Meaney, 1993; Rice et al., 2008; Veenema, 2009). Generally, early life stress in animals enhances anxiety- and depression-like behaviour, and is accompanied by functional changes of the hypothalamic-pituitary-adrenal (HPA) axis, one of the major stress systems of the organism. In addition, early life stress alters social and aggressive behaviours as well (Veenema et al., 2006, 2007b; Toth et al., 2008; Veenema and Neumann, 2009). The fact that concomitant changes in both anxiety/fear-related responses and aggression are a consequence of negative early life experiences further underscores the close interplay between aggression and anxiety. Therefore, early life stress is an important model in the study of mechanisms of excessive aggressive behaviour and their link to anxiety.

\section{SELECTIVE BREEDING}

Breeding for a selected behavioural phenotype is an important approach to reveal neurochemical correlates of aggressive behaviour. Several lines of mice have been selected for differences in attack latency, including the SAL and LAL mice (van Oortmerssen and Bakker, 1981), the Turku aggressive and non-aggressive mice (Sandnabba, 1996), and the North Carolina 900 and 100 mice (Gariepy et al., 1996). Among these selection lines, the SAL mice show the most excessive and abnormal forms of aggression (Sluyter et al., 2003; Haller and Kruk, 2006; Natarajan et al., 2009). However, a significant difference in anxiety-related behaviours between SAL and LAL mice has not been consistently found (Hogg et al., 2000; Veenema et al., 2003a). In contrast, high aggression in the Turku mice is associated with low levels of anxiety (Nyberg et al., 2003), 
whereas high aggression in the North Carolina mice is accompanied by high levels of anxiety (Nehrenberg et al., 2009). Interestingly, both aggression and anxiety were reduced by acute diazepam treatment in the aggressive North Carolina 900 mice (Nehrenberg et al., 2009). These examples demonstrate that selective breeding for aggression can result in concomitant changes in anxiety-related behaviours, albeit in different directions.

In rats, selective breeding for aggression is less common. The Novosibirsk Norway rats are selected for high and low aggression towards humans and, therefore, differ in defensive, rather than offensive, aggression (Naumenko et al., 1989; Plyusnina and Oskina, 1997). Nevertheless, this model is of interest as the high aggressive Novosibirsk rats show a high level of anxiety (Popova et al., 1999). In an out-bred laboratory strain of wild-type rats, a wide range of aggressive behaviours was observed, although individuals with extremes in aggressive behaviour did not differ in anxiety-related behaviours (de Boer et al., 2003).

In our laboratory, we selectively breed $\mathrm{HAB}$ and $\mathrm{LAB}$ Wistar rats for differences in trait anxiety as opposed to aggression. These rat lines have been extensively characterized in terms of emotionality and general stress coping strategies, as well as the underlying brain and neuroendocrine mechanisms (Landgraf and Wigger, 2002; Landgraf et al., 2007; Veenema and Neumann, 2007). Here, we will present evidence that the $\mathrm{HAB}$ and $\mathrm{LAB}$ lines provide a promising model for studying brain mechanisms of high and abnormal forms of aggression and their link to trait anxiety.

\section{HAB AND LAB RATS: AN ANIMAL MODEL FOR EXTREMES IN ANXIETY AND AGGRESSION}

$\mathrm{HAB}$ and $\mathrm{LAB}$ rats were originally bred for extremes in anxietyrelated behaviour with the primary goal of establishing a robust behavioural phenotype (HAB) that mimics as many symptoms of human anxiety- (and depression-) related disorders as possible. This approach enabled us to reveal neuroendocrine, neuronal, and neurogenetic parameters directly linked to differences in trait anxiety. HAB and LAB rats are particularly useful as they (i) allow the identification of intracerebral pathways underlying trait anxiety, (ii) show differential sensitivity to anxiolytic/antidepressive substances with high responsiveness in $\mathrm{HAB}$ and almost no responsiveness in LAB rats (Keck et al., 2003, 2005), and (iii) enable the identification of candidate genes and gene polymorphisms underlying trait anxiety (Murgatroyd et al., 2004; Landgraf et al., 2007). Over the last several years, we have used HAB and $\mathrm{LAB}$ rats to identify possible links between innate anxiety and various aspects of complex social behaviours including social interaction (Henniger et al., 2000), maternal care (Neumann et al., 2005a; Bosch and Neumann, 2008), maternal aggression (Bosch et al., 2005), and intermale aggression (Beiderbeck et al., 2007; Veenema et al., 2007a). During the course of these studies, the male $\mathrm{LAB}$ rat has emerged as an interesting model for abnormal social behaviour, including excessive aggression (Veenema and Neumann, 2007) (Figure 1).

\section{HISTORY OF HAB AND LAB RATS}

Starting in 1993, commercially available Wistar rats (Charles River, Sulzfeld, Germany) were selected and further bred for extremes in anxiety-related behaviour as measured on the EPM resulting in the $\mathrm{HAB}$ and LAB breeding lines (Liebsch et al., 1998b). One year later,

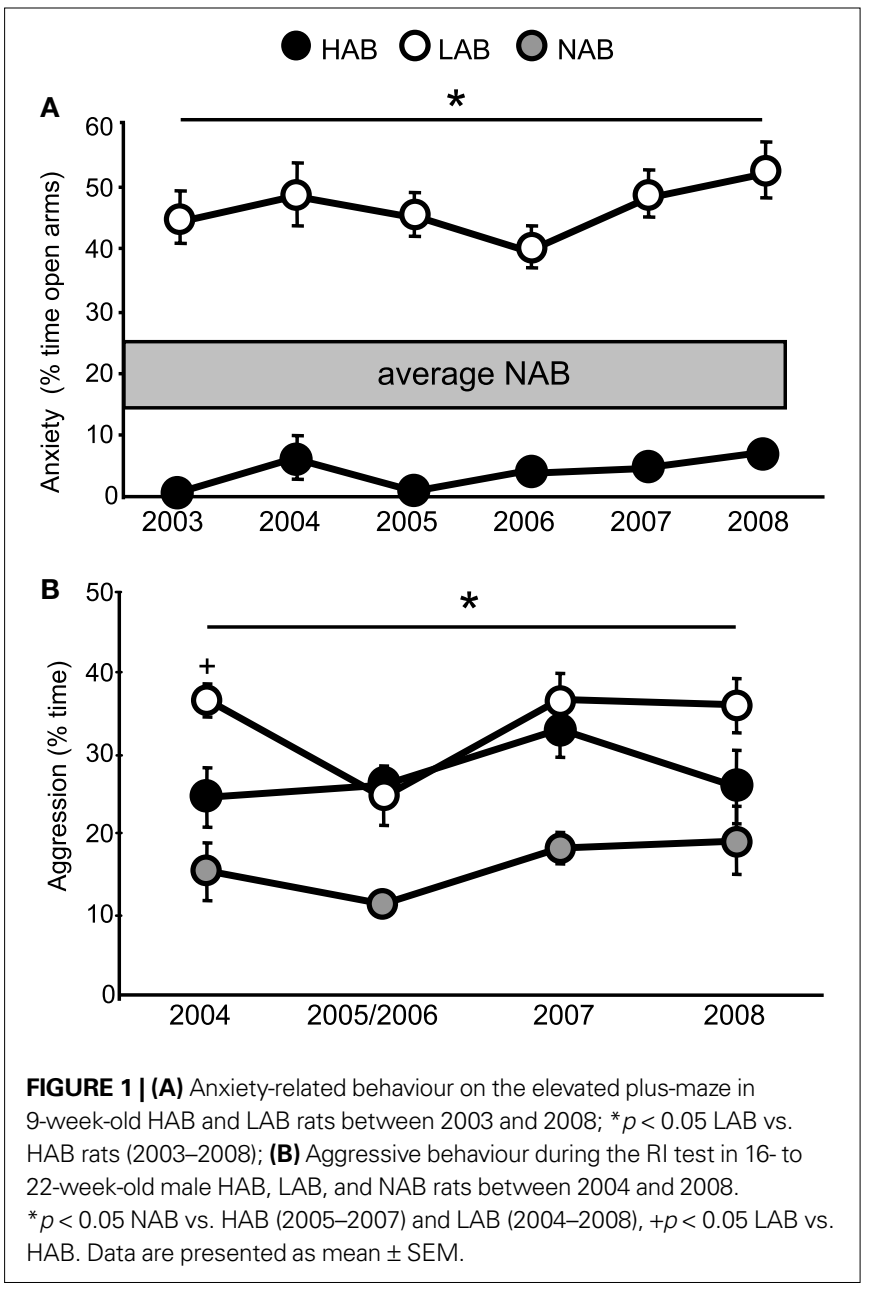

Wistar rats bred for low vs. high behavioural performance in an active avoidance task (i.e. the Y-maze) at the University of Leipzig, Germany (Hess et al., 1992), were crossbred into the HAB and LAB lines, respectively, in order to improve the fitness of these out-bred lines. Between 1993 and 2003, breeding of HAB and LAB rats was performed exclusively at the Max Planck Institute for Psychiatry in Munich. In 2003, the HAB and LAB breeding lines were transferred to our laboratory at the University of Regensburg, which is currently the only location maintaining these lines. Throughout their existence, the $\mathrm{HAB}$ and $\mathrm{LAB}$ rat lines have been treated identical in terms of housing, animal care, mating and behavioural testing, and, importantly, sibling mating has been strictly avoided. The bidirectional breeding and selection procedure of $\mathrm{HAB}$ and $\mathrm{LAB}$ rats for either further breeding or experimental use is based on their performance on the EPM, which is tested between 9 and 10 weeks of age. The line difference in anxiety-related behaviour is stable (Figure 1A) and present over all seasons under our controlled laboratory conditions $(12 / 12 \mathrm{~h}$ light/dark cycle with lights on at 6:00 a.m., $21 \pm 1{ }^{\circ} \mathrm{C}, 60 \%$ humidity, standard rat chow and tap water ad libitum). However, LAB rats have even lower levels of anxiety during the summer season (Figure 2A). Male and female $\mathrm{HAB}$ and $\mathrm{LAB}$ rats are selected for further breeding only if the percentage of time spent on the open arms of the maze is below $5 \%$ or above $45 \%$, respectively. For experimental purposes, HAB rats 

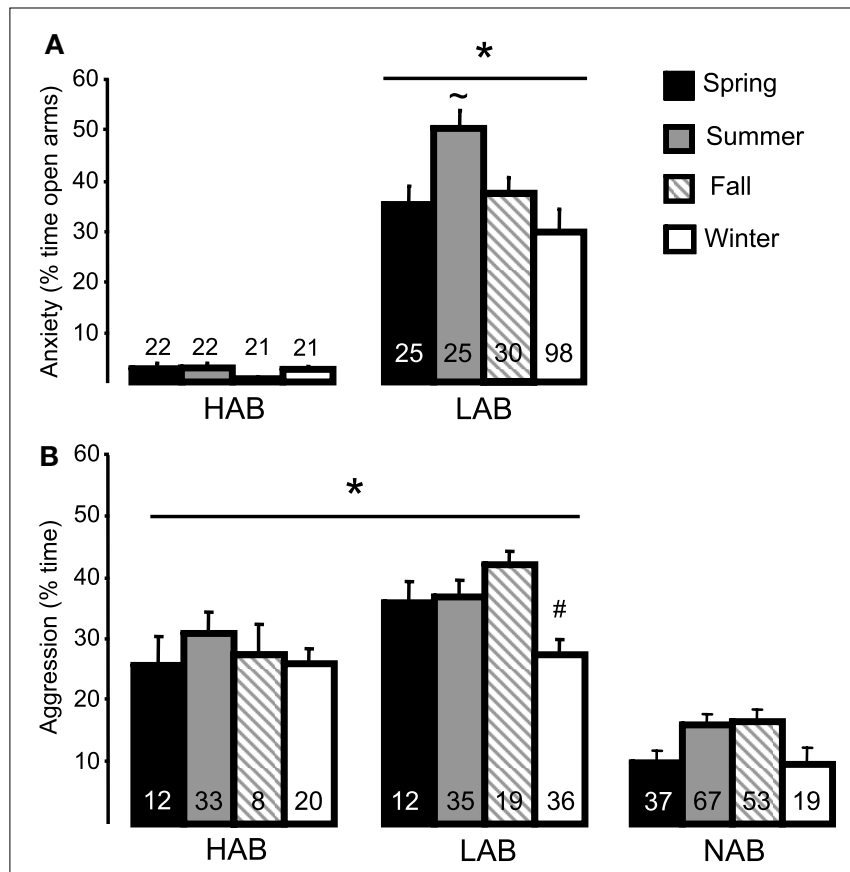

FIGURE 2 | (A) Anxiety-related behaviour on the EPM as reflected by the percentage of time on the open arms measured in 9-week-old male HAB and $L A B$ rats $\left({ }^{*} p<0.05\right.$ vs. $H A B$ at any time, $\sim p<0.05$ vs. other 3 seasons), and (B) aggressive behaviour of 16- to 22-week-old male HAB, LAB, and NAB rats $\left({ }^{*} p<0.05\right.$ vs. NAB, $\# p<0.05$ vs. summer and fall) during the four seasons. Numbers in columns indicate group size. Data are presented as mean + SEM.

with less then $10 \%$ and $\mathrm{LAB}$ rats with more then $35 \%$ time on the open arms are used. These strict criteria are met by approximately 80-90\% of all offspring.

Each behavioural test established to characterize a particular anxiety-related phenotype has its own limitations. Therefore, it is important that the differences in anxiety-related behaviour between $\mathrm{HAB}$ and $\mathrm{LAB}$ rats are not restricted to the selection criterion, i.e. their behaviour on the EPM. In the case of HAB and $\mathrm{LAB}$ rats, differences have also been confirmed in other validated tests of anxiety, including the open field, the black-white box (Henniger et al., 2000; Slattery and Neumann, 2010), the modified hole board (Ohl et al., 2001), and in tests for conditioned anxiety (Muigg et al., 2008). Moreover, the HAB/LAB differences in anxiety-related behaviour are (i) independent of gender, as both male and female offspring meet the selection criteria (Bosch et al., 2005; Bosch and Neumann, 2008), and (ii) independent of age, as $\mathrm{HAB}$ pups show more ultrasound vocalization when separated from their mother during the first week of life, and differences in EPM behaviour are consistent between 9 weeks and 19 months of age (Landgraf and Wigger, 2002), and (iii) robust as behavioural outcomes have been consistent over the last 6 years (Figure 1A) and across several European laboratories (Salome et al., 2002; Veenema et al., 2007a). Importantly, both HAB and LAB rats significantly differ from non-selected rats purchased from Charles River (NAB), which show intermediate behavioural and emotional responses in a variety of tests (Ohl et al., 2001; Bosch et al., 2005; Veenema et al., 2007a). Taken together, these facts suggest some success in our goal to bidirectionally breed for extremes in anxiety-related behaviour with $\mathrm{HAB}$ rats showing the highest and $\mathrm{LAB}$ rats showing the lowest avoidance of an aversive environment.

It is well accepted that anxiety and depression represent overlapping symptoms which cannot be easily dissociated (Cryan and Holmes, 2005; Grillon et al., 2005; Landgraf et al., 2007). In this context it is important to note that the selection for extremes in trait anxiety is paralleled by a divergence in depression-related behaviour. Thus, $\mathrm{HAB}$ rats float more and struggle less during a single 10 -min exposure to the forced swim test $\left(21-23^{\circ} \mathrm{C}\right)$ indicative of depression-like behaviour, whereas LAB rats show the opposite and are more active (Liebsch et al., 1998b; Wiehager et al., 2009; Slattery and Neumann, 2010). In addition, long-term treatment with the serotonin-reuptake inhibitor paroxetine, an antidepressant, reversed the passive, depression-like behaviour of male $\mathrm{HAB}$ rats to the level of active coping strategy seen in LABs (Keck et al., 2003). Other findings in $\mathrm{HAB}$ rats demonstrate a hyper-responsiveness of the HPA axis to a mild emotional stressor (Landgraf et al., 1999) and a pathological adrenocorticotropic hormone $(\mathrm{ACTH})$ response during the combined dexamethasone/corticotropin-releasing hormone challenge test (Keck et al., 2003), a diagnostic marker for major depression (Holsboer et al., 1994). Together, these results indicate the high potential of $\mathrm{HAB}$ rats as a model for anxiety with co-morbid depression.

\section{AGGRESSION AND OTHER SOCIAL BEHAVIOURS IN HAB AND LAB RATS}

The bidirectional breeding for high and low anxiety has also resulted in distinct phenotypes with respect to various aspects of social behaviour summarized in Table 1. For example, differences in the overall level of social interaction, social discrimination abilities, maternal behaviour and intermale aggression could be revealed. In the modified hole board test, LAB rats spent less time in social contact with their cage mates than HAB rats (Ohl et al., 2001). LAB males also have a slightly impaired ability to discriminate between a novel and a familiar juvenile to which they were exposed $30 \mathrm{~min}$ before (Landgraf and Wigger, 2002). In a social preference test, which consists of measuring the time the experimental animal spends in contact with a caged male rat vs. the time the animal spends with an empty cage, LAB rats do not show social preference, whereas both HAB and NAB rats do (Lukas et al., 2008). These data suggest that LAB rats are likely to have a lower "need" for social support in a novel environment, no preference for social vs. non-social stimuli or, alternatively, even an aversion to social interaction in general (social phobia). In fact, it cannot be ruled out that social avoidance may influence the results of discrimination tasks. Conversely, in a different social interaction test, pairs of male $\mathrm{LAB}$ rats spent more time in active social interaction compared with pairs of HAB males (Henniger et al., 2000), but an increased display of aggression in an unavoidable social interaction might have contributed to the increased time spent in active social interactions. Indeed, breeding line-dependent differences in intermale aggression have been found under varying experimental conditions such as among cage-mates in the home cage (Henniger et al., 2000), towards an intruder in the RI test (see below), and towards a resident in the social defeat test (Frank et al., 2006). In each case, $\mathrm{LAB}$ rats were consistently more aggressive. Interestingly, in the RI test, $\mathrm{LAB}$ males strongly differ from $\mathrm{HAB}$ and $\mathrm{NAB}$ rats not only in 
Table 1 | Overview of the behavioural differences between LAB and HAB rats.

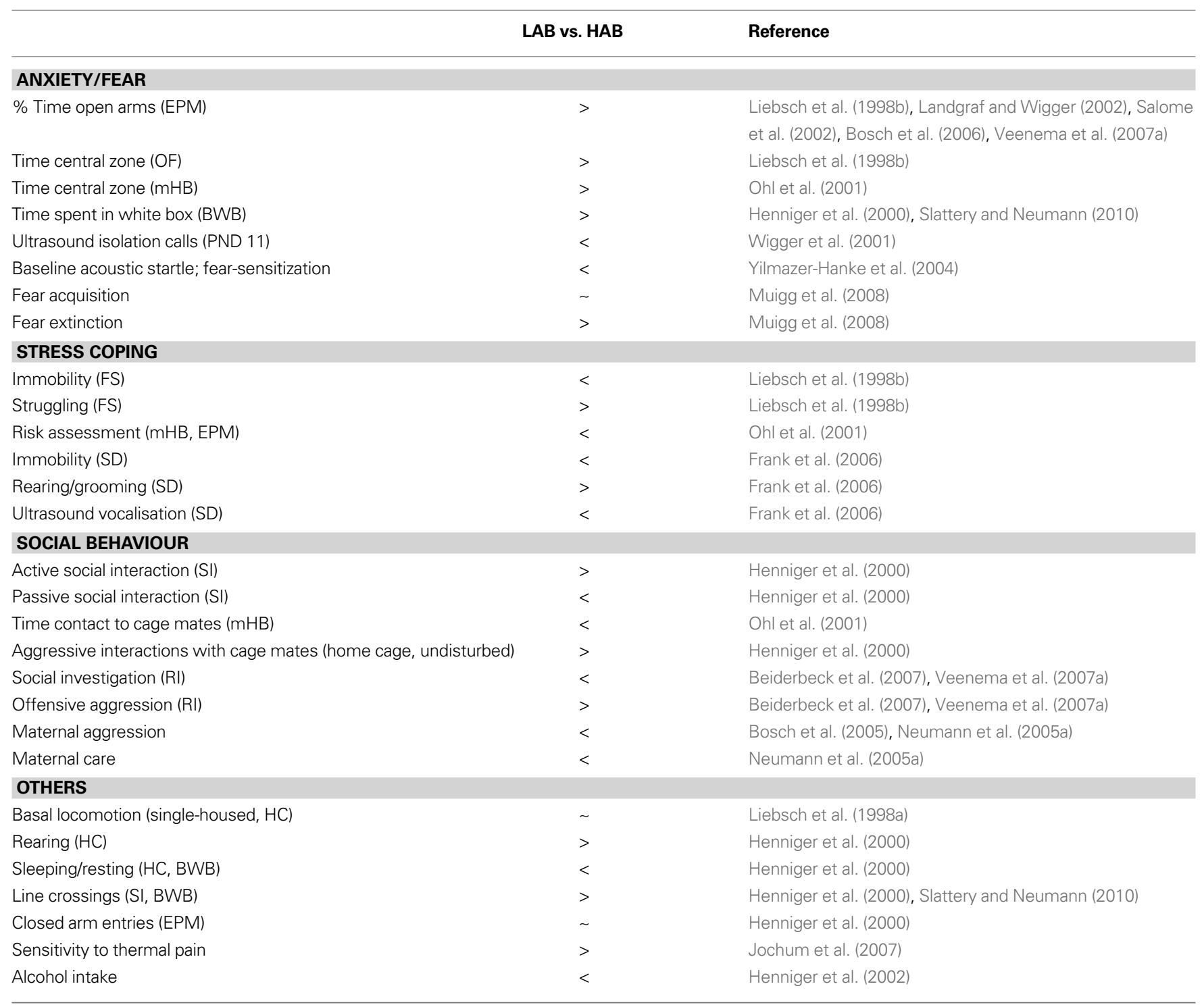

Symbols indicate the following: $>$, higher in $\angle A B$ rats; $<$, lower in $\angle A B$ rats; $\sim$, no difference between $\angle A B$ and $H A B$ rats.

$B W B$, black-white box; EPM, elevated plus-maze; FS, forced swim test; HC, home cage; $m H B$, modified hole board; OF, open field; PND, postnatal day; RI, resident-intruder test; $S D$, social defeat; SI, social interaction.

aggression (see below), but also in non-aggressive social behaviour, as they spend less time in non-aggressive social interaction with the intruder (Beiderbeck et al., 2007; Veenema et al., 2007a). The behavioural differences in intermale aggression as seen in the RI test will be discussed in detail below.

Profound differences in social and aggressive behaviours are also observed in female $\mathrm{HAB}$ and $\mathrm{LAB}$ rats, especially during lactation. HAB dams generally display a more protective style of maternal behaviour, as they leave the nest less often and spend more time on the offspring in an arched back nursing position (Bosch et al., 2005; Neumann et al., 2005a; Bosch and Neumann, 2008). The protective behaviour of $\mathrm{HAB}$ dams is also reflected by an increased level of maternal aggression towards a female intruder rat during the maternal defence test (Bosch et al., 2005; Bosch and Neumann, 2008). Differences in the brain oxytocin and AVP systems between
HAB and LAB dams were found to contribute to these distinct forms of maternal behaviour (Bosch et al., 2005; Bosch and Neumann, 2008).

\section{LAB RATS AS A MODEL FOR HIGH AND ABNORMAL AGGRESSION}

Although LAB rats originally served as breeding controls for HABs, continuous bidirectional breeding for anxiety-related behaviour resulted in two lines of Wistar rats with distinct behavioural phenotypes compared with NAB rats. Accordingly, LAB rats by themselves are of potential interest as an animal model because of their altered phenotype, which includes extremely low anxiety and fear responses, reduced risk assessment, high exploration, active stress coping style, and high and abnormal forms of aggressive behaviours in different social settings. Of particular interest for this review is the finding of a high level of intermale aggression in LAB residents, 
which remained consistent over the last 6 years (Figure 1B), and an intermediate level of aggression in $\mathrm{HAB}$ residents during the RI test as compared with NAB residents (Figure 1B).

In LAB rats, there was only a small seasonal effect with a reduction in the level of aggression during the winter season under the experimental conditions in our laboratory with constant light/dark cycle, room temperature, and humidity (Figure 2B). A detailed analysis of the behavioural profile during the RI test (using an unfamiliar NAB male rat as standard intruder) indicates that LAB rats consistently show the highest level of aggression as indicated by more time spent with total aggressive behaviour (Figure 3A), lateral threat (Figures 3C,E), and offensive upright (Figures 3D,F).

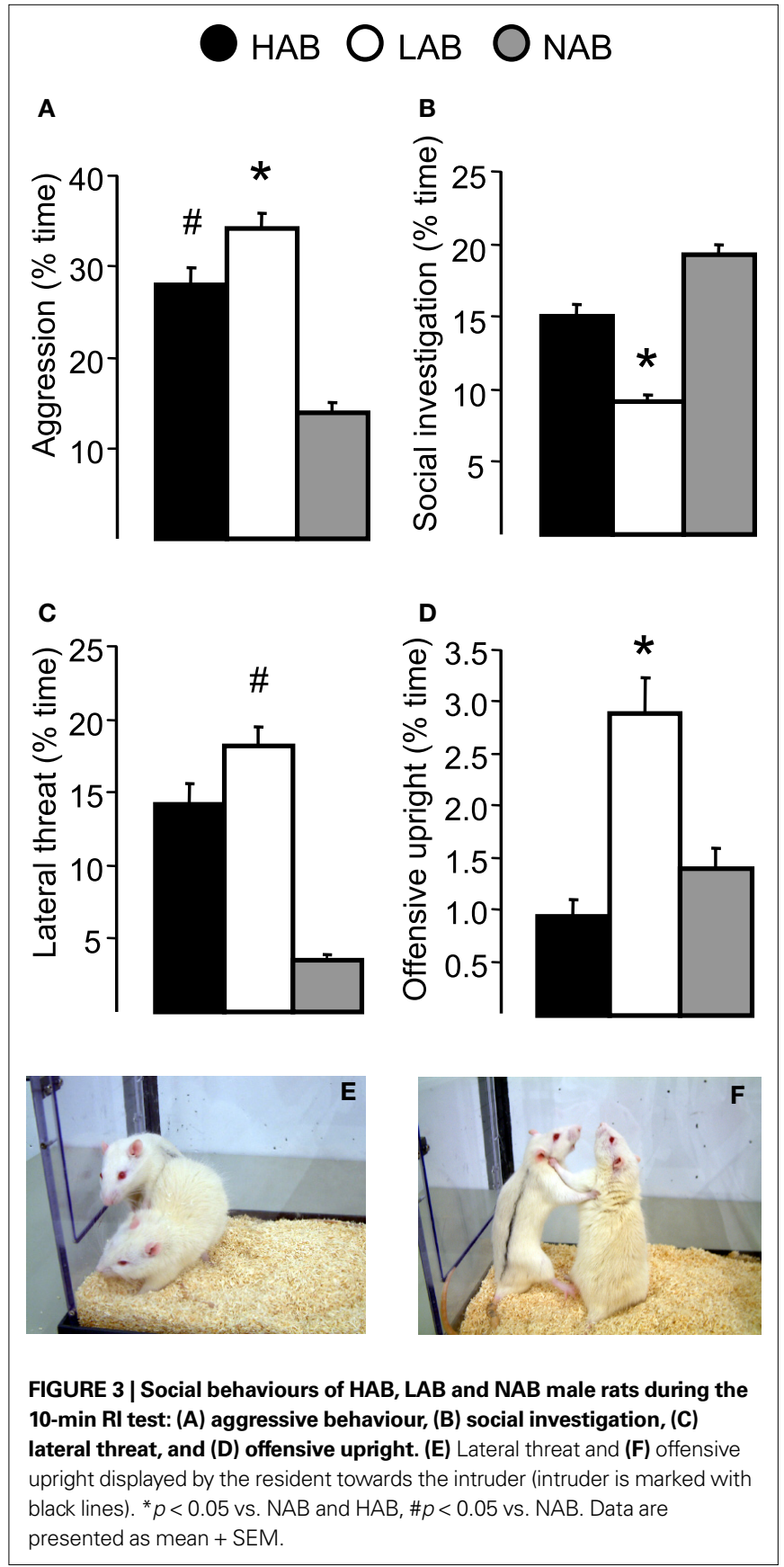

Lateral threat, in particular, is a major element of aggression which often precedes an attack and comprises almost half of the total aggression time in both $\mathrm{HAB}$ and $\mathrm{LAB}$ rats. Moreover, male LAB rats spend less time with social investigation compared with $\mathrm{HAB}$ and $\mathrm{NAB}$ rats (Figure $3 \mathrm{~B}$ ). The excessive aggression of $\mathrm{LAB}$ males is also reflected by the fact that almost $80 \%$ of all LAB rats tested over the last 6 years showed aggressive behaviour for more than $15 \%$ of the time of the RI test, and almost $10 \%$ of LABs showed aggressive behaviour for more than $55 \%$ of the time (Figure 4). In contrast, none of the $\mathrm{HAB}$ or $\mathrm{NAB}$ rats reached this high level of aggression. In fact, more than $50 \%$ of the NAB rats did not reach the $15 \%$ of aggression level (Figure 4). Thus, the LAB, and to a lesser extent the $\mathrm{HAB}$, breeding line are characterized by remarkable aggressive behaviour compared with non-selected Wistar rats.
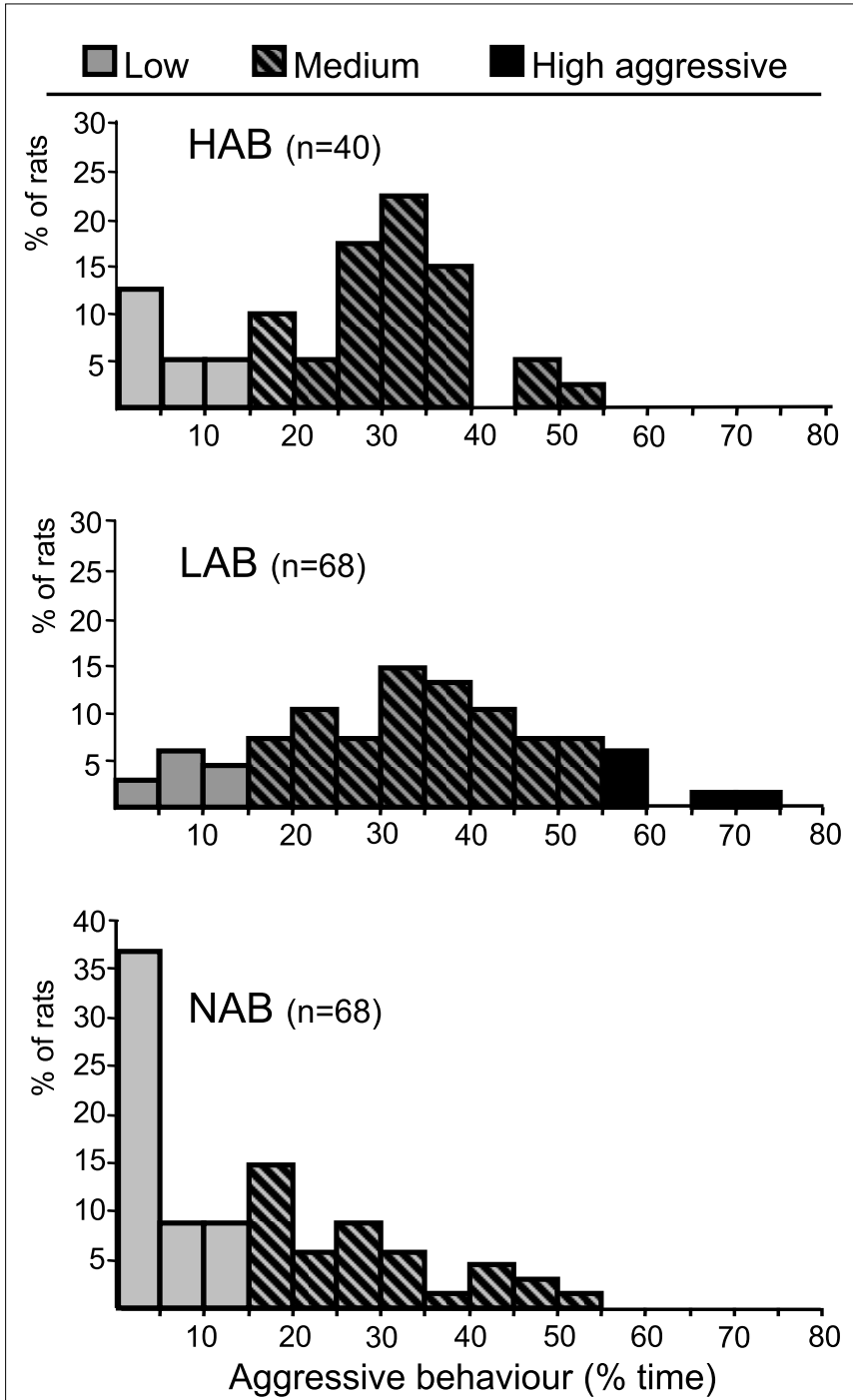

FIGURE 4 | Allocation of HAB, LAB, and NAB male in low-, medium- and high-aggressive. Rats are categorized according to their level of aggressive behaviour expressed as percentage of time in the RI test (low-aggressive: less than 15\% aggressive behaviour; medium-aggressive: between 15 and $55 \%$ aggressive behaviour; high-aggressive: more than 55\% aggressive behaviour) 
Is the high level of aggressive behaviour in male LAB rats accompanied by the display of abnormal forms of aggression? According to the definition given above, abnormal aggression occurs when species-specific rules are disregarded, which, e.g., would be reflected in the RI test by attacks directed towards vulnerable (head, belly, genitals) as opposed to less vulnerable (flanks and back) body parts of the male intruder. Indeed, in a pilot study we could observe that $90 \%$ of $\mathrm{LAB}$ and $70 \%$ of the HAB residents, but only $20 \%$ of $\mathrm{NAB}$ rats attacked vulnerable body parts of a male intruder rat (Figure 5). Similarly, 70\% of resident LAB males attacked a nonoestrus female intruder, whereas only $10 \%$ of $\mathrm{HAB}$ and NAB residents did attack the female (Figure 5). Also, all LAB (100\%), but only $38 \%$ of NAB males attacked a narcotized male intruder. We speculate that, in the case of the anesthetized male intruder, the lack of defensive signalling (due to the lack of vibrissae activity) (Blanchard et al., 1977) may have triggered aggressive behaviour in $\mathrm{LAB}$ rats. Taken together, our behavioural observations demonstrate that both an extremely low and a high level of innate anxiety can be associated with high and abnormal forms of aggressive behaviour. As LAB rats display high and abnormal forms of aggression and avoid non-aggressive social interactions, they emerge as an interesting model for pathological social behaviours in general.

\section{CORRELATION BETWEEN AGGRESSION AND ANXIETY IN LAB AND HAB MALES}

The unique phenotypes of $\mathrm{LAB}$ and $\mathrm{HAB}$ rats with consistent differences in both innate anxiety and intermale aggression provide the chance to correlate parameters of anxiety- and aggression-related behaviours. Both $\mathrm{LAB}$ and $\mathrm{HAB}$ rats show a higher level of aggression than $\mathrm{NAB}$ rats indicating that both high as well as low trait anxiety can be associated with relatively high aggression scores

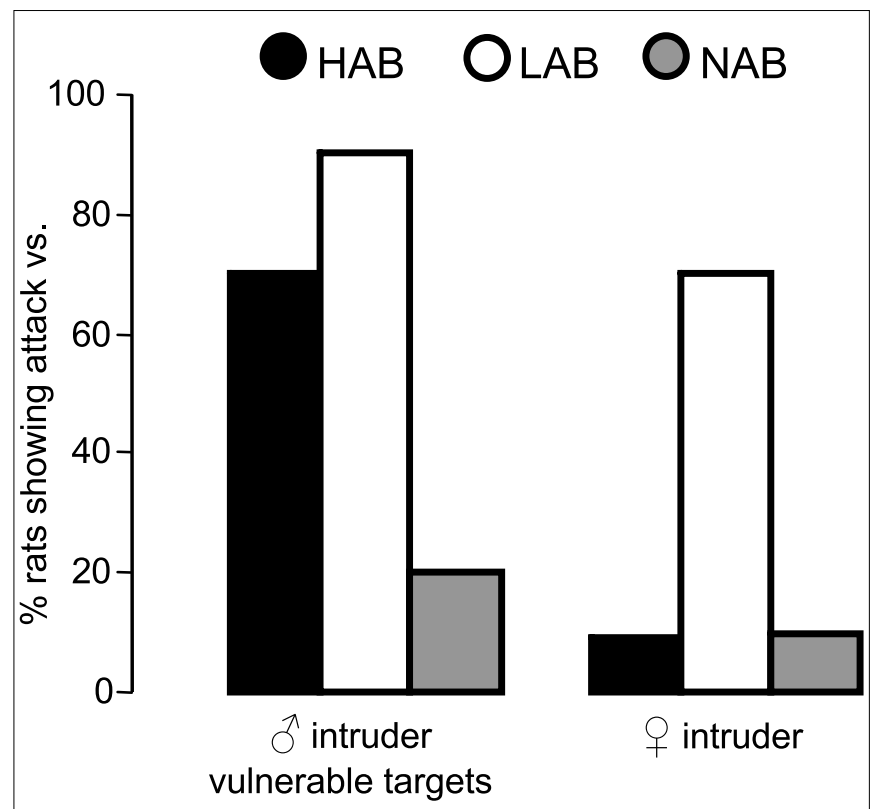

FIGURE 5 | Line-specific differences in abnormal aggression as indicated by the percentage of $\mathrm{HAB}, \mathrm{LAB}$ and NAB male rats attacking vulnerable body parts of a male intruder (left) or a female intruder (right) during the RI test in their home cage.
(Figures 1 and 2), whereas the intermediate level of anxiety-related behaviour as found in NAB rats was accompanied by a low level of intermale aggression. In a previous analysis performed on a small sample of rats ( $n=7-9$ in the LAB, HAB, and NAB group) we reported a negative linear correlation between anxiety and intermale aggression (Veenema et al., 2007a). In detail, the highest aggression was found in LAB rats that had the lowest level of anxiety. We are currently investigating a possible correlation between aggression and anxiety in a larger number of $\mathrm{LAB}, \mathrm{HAB}$ and NAB rats, as our recent data indicate that a $U$-shaped correlation may emerge, i.e., that both HAB and LAB males show a higher level of aggression than NAB males. This may indicate that both high and low trait anxiety can be associated with relatively high aggression scores (Figure 1).

\section{NEUROBIOLOGICAL CORRELATES OF AGGRESSION AND ANXIETY IN LAB AND HAB RATS}

The complex and fine-tuned emotional and social responsiveness of an individual is regulated by numerous neurochemicals including classical neurotransmitters and neuromodulators like neuropeptides and hormones. Preclinical research on high and abnormal aggression has focused mainly on the role of HPA axis hormones, the neuropeptide AVP, and neurotransmitters like 5-HT and gamma-aminobutyric acid (GABA; for reviews see de Almeida et al., 2005; Haller et al., 2005). Using LAB and $\mathrm{HAB}$ rats, we have found experimental evidence that differences in HPA axis responsiveness and the AVP and 5-HT systems do not only contribute to the extremes in anxiety-related behaviours of these animals (Landgraf et al., 2007), but also to their aggression phenotypes.

\section{HPA AXIS}

The HPA axis is one of the major stress systems and is regulated by the release of corticotropin-releasing hormone and AVP from the paraventricular nucleus (PVN) into the pituitary, which stimulates the secretion of ACTH into the blood. ACTH, in turn, triggers the adrenal release of glucocorticoids (cortisol in humans, corticosterone in rats), which facilitate physiological and behavioural adaptations to a stressor at multiple peripheral and brain levels. Dysregulation of the HPA axis has been frequently linked to anxiety- and depression-related disorders, as well as to violence and abnormal aggression (Plotsky et al., 1998; Mello et al., 2003; de Kloet et al., 2005). Although data from preclinical studies are conflicting, they generally implicate glucocorticoids as important regulators of aggressive behaviour (Haller et al., 1998, 2001; Summers et al., 2005b). Paradoxically, both acute high and chronically low levels of circulating glucocorticoids have been associated with high aggression (see above; Hayden-Hixson and Ferris, 1991; Haller et al., 2000; Kruk et al., 2004; Summers and Winberg, 2006). For example, an acute rise in glucocorticoids promotes intermale aggression in rodents (Mikics et al., 2004) and might be associated with a state of hyperarousal and sudden outbursts of aggression. Acute blockade of glucocorticoid synthesis results in reduced aggression in male rats, an effect which is reversible by corticosterone treatment (Mikics et al., 2004). In contrast to these findings, low HPA axis reactivity (Veenema et al., 2003b, 2005) or chronically low glucocorticoid levels (Haller et al., 2001, 2005; Kim and Haller, 2007) also result 
in excessive aggression and a higher frequency of attacks directed towards vulnerable body parts and might underlie pathological forms of aggression including violence.

The distinct behavioural phenotypes of the $\mathrm{LAB}$ and $\mathrm{HAB}$ breeding lines are accompanied by stressor-dependent differences in neuroendocrine responses. When exposed to a non-social stressor, e.g. a novel environment, $\mathrm{HAB}$ rats show a more pronounced ACTH and corticosterone secretory response (Landgraf et al., 1999; Neumann et al., 2005b) and elevated neuronal responsiveness in the PVN, the medial preoptic area and the locus coeruleus (Salome et al., 2004). In contrast, exposure to a social conflict situation seems more threatening to LAB rats (Veenema and Neumann, 2007). When exposed as an intruder during the social defeat test, LAB males show a higher HPA axis response despite showing fewer signs of emotional distress like ultrasound vocalization and freezing (Frank et al., 2006). Moreover, higher ACTH and corticosterone responses are found in $\mathrm{LAB}$ compared with $\mathrm{HAB}$ and $\mathrm{NAB}$ rats when exposed as resident to the RI test (Veenema et al., 2007a). The elevated neuroendocrine responses are also accompanied by higher neuronal activation of the PVN and the central amygdala in LAB compared with HAB resident males (Veenema et al., 2007a). These results suggest a generally higher responsiveness to social stressors in LAB males. However, as LABs generally display a higher level of aggression, two possibilities may explain the elevated stress responsiveness to social stimuli in LAB males: (i) their active behavioural coping style increases metabolic demands or (ii) social stimuli are perceived as more of a threat, which is translated into higher levels of aggression when the stimulus can not be avoided. In support for the latter possibility, an acute rise in glucocorticoids is required to initiate aggressive behaviour in rodents as discussed above (Clarke and File, 1983; Haller et al., 2000; Kruk et al., 2004; Mikics et al., 2004). In general, LAB and HAB rats mimic clinical reports in which high and abnormal aggression have been linked to either a state of high or low glucocorticoid function making them an interesting tool to further explore the link between HPA axis dysregulation and high and abnormal forms of aggression, and distinct anxiety levels.

\section{BRAIN AVP SYSTEM}

More than any other class of neuroactive substances, brain neuropeptides are critically involved in emotionality and complex social behaviours. In particular, the nonapeptide AVP and the closely related oxytocin have been extensively characterized with respect to their ability to modulate anxiety- and depression-related behaviours and a broad variety of social behaviours including social cognition, pair-bonding, maternal behaviour, and aggression. With respect to intermale aggression and anxiety-related behaviour, brain AVP seems to play an especially important role. AVP is synthesized in the hypothalamic PVN and supraoptic nucleus as part of the hypothalamo-neurohypophysial system, and in the bed nucleus of the stria terminalis (BST), medial amygdala and suprachiasmatic nucleus. AVP can be released within distinct brain regions as a neurotransmitter, but generally may act more like a neuromodulator. Via the latter type of information processing, the brain is liberated from the constraints of wiring, as locally released neuropeptides can reach any neighbouring brain region by diffusion thereby increasing the regulatory capacity of neuropeptidergic neurons (Landgraf and
Neumann, 2004). Several stress-related, fear-provoking and social stimuli were found to trigger local release of AVP within distinct brain regions, such as the PVN, where AVP can be released from dendrites and perikarya, as well as other regions outside the hypothalamus (Engelmann et al., 2004; Landgraf and Neumann, 2004; Veenema and Neumann, 2008).

Brain AVP has been implicated in aggressive behaviour in several species including rats, mice, hamsters, birds, and humans (Koolhaas et al., 1990; Ferris, 1992; Albers and Bamshad, 1998; Coccaro et al., 1998; Veenema and Neumann, 2007; Goodson, 2008). However, conflicting data have been reported on AVP as a potential modulator of intermale aggression. In hamsters, local injections of AVP into brain regions relevant for aggression like the anterior hypothalamus, BST, and lateral septum promote aggressive behaviour (Ferris and Potegal, 1988; Irvin et al., 1990). Moreover, a higher density of AVP immunoreactivity and V1a receptors were found in the lateral septum of highly vs. less aggressive Peromyscus mice (Bester-Meredith et al., 1999). In rats, testosterone-dependent AVP pathways, which originate in the BST/medial amygdala and project to the lateral septum (de Vries and Buijs, 1983), are diminished after castration (de Vries et al., 1984) as are levels of aggression (Koolhaas et al., 1990). Injection of AVP into the medial amygdala or lateral septum of castrated male rats reverses (i.e., increases) the aggression level to that seen in intact males (Koolhaas et al., 1990, 1991). In humans, AVP concentration in the cerebrospinal fluid correlates positively with the level of aggression in personalitydisordered subjects (Coccaro et al., 1998). Recently, intranasal AVP has been shown to alter aspects of social communication in men, as a decrease in the perception of friendly faces and an increase in the perception of threat and anger when exposed to neutral faces were found in AVP-treated healthy men (Thompson et al., 2004). Together, these data provide evidence for a positive link between brain AVP and aggression, but there are also reports demonstrating the opposite. For example, a lower AVP cell number in the BST and a lower density of AVP fibres within the lateral septum were found in two animal models, i.e. in SAL vs. LAL mice and in high vs. low aggressive wild-type rats (Compaan et al., 1993; Everts et al., 1997). These contradictory findings led us to question the role of endogenous brain AVP within the lateral septum during the expression of intermale aggression.

There is also substantial evidence that AVP is an important anxiogenic factor (for reviews see Ring, 2005; Landgraf, 2006; Landgraf et al., 2007). Accordingly, dysregulation of the brain AVP system, especially over-activity of AVP neurons, is likely to contribute to the etiology and symptomatology of anxiety- and depression-related disorders (Murgatroyd et al., 2004; Simon et al., 2008; Surget and Belzung, 2008). Based on the behavioural and neuroendocrine phenotype of $\mathrm{LAB}$ and $\mathrm{HAB}$ rats, together with the anxiogenic effects of AVP, the AVP gene has been considered a candidate gene for anxiety (for review see Landgraf et al., 2007). Indeed, characterization of the activity of the brain AVP system in LAB and HAB rats has revealed an elevated expression of the AVP gene in male (Keck et al., 2002; Wigger et al., 2004) and female (Bosch and Neumann, 2010) $\mathrm{HAB}$ rats without changes in central AVP V1a receptor expression or binding (Wigger et al., 2004; Bosch and Neumann, 2010). Sequence analysis of the AVP gene promoter revealed 10 single nucleotide polymorphisms within the AVP promoter of HAB rats, 
one of which was localized in a transcription factor DNA-binding site known as CArG box (Murgatroyd et al., 2004). Mutation within the CArG box impairs the binding of a transcriptional repressor, i.e. the CArG box binding factor A, resulting in disinhibition of AVP gene expression. Overexpression of the AVP gene and subsequent elevated levels of local AVP release within the PVN could contribute not only to the high level of anxiety (Keck et al., 2003), but also to the elevated HPA axis response to non-social stimuli observed in HABs (Keck et al., 2002).

Moreover, the differences in brain AVP system activity and, consequently, AVP availability in LAB and $\mathrm{HAB}$ rats together with their distinct behavioural phenotypes provided the opportunity to reveal the contribution of endogenous AVP to a given aggression phenotype. Thus, we compared local AVP release patterns between the breeding lines during the RI test using intracerebral microdialysis. Within the lateral septum of LAB males, there was a significant decrease in AVP release during the display of intermale aggression accompanied by a lower neuronal activation compared with HAB males, in which local AVP release tended to increase (Beiderbeck et al., 2007). In contrast to our expectation, increasing the availability of AVP in the extracellular fluid within the lateral septum of LAB rats by application of synthetic AVP via reversed microdialysis did not alter the level of aggressive behaviour, but resulted instead in an increase in anxiety on the EPM (Beiderbeck et al., 2007). Further, blockade of local V1a receptors by the selective AVP V1a receptor antagonist $\mathrm{d}\left(\mathrm{CH}_{2}\right)_{5} \mathrm{Tyr}(\mathrm{Me}) \mathrm{AVP}$ (kindly provided by Dr. Maurice Manning, Toledo, USA) did not affect aggressive behaviour of HAB rats. Interestingly, however, the V1a receptor antagonist reduced the duration of general social investigation during the RI test in $\mathrm{HAB}$ rats to the low level seen in LAB rats.

Taken together, despite differences in AVP release patterns within the septum found in $\mathrm{LAB}$ and HAB rats during the RI test, a causal role of locally released AVP in the expression of intermale aggression could not be confirmed. Therefore, we recently suggested that the aggression-induced change in septal AVP release may modulate closely related adaptive behaviours like anxiety- and fear-responses, stress coping, or social cognition relevant for future behavioural strategies rather than aggression itself (Veenema and Neumann, 2008). In this context it is of interest to note that differences in local AVP release within the septum and within the BST are also associated with differences in aggression in NAB rats (Veenema et al., 2010). In NAB males classified as being aggressive during the RI test, AVP release within the septum significantly increased, whereas it remained unchanged in non-aggressive NAB rats. However, local application of synthetic AVP to non-aggressive NAB rats did not alter their respective aggression level, even though the anxiogenic effect of AVP could be confirmed on the EPM. Local application of the $\mathrm{V} 1 \mathrm{a}$ receptor antagonist to aggressive $\mathrm{NAB}$ rats did reduce their aggression level.

In addition to the medio-lateral septum, the BST has been suggested in the regulation of intermale aggression (Hines et al., 1992). Local microdialysis revealed differences in AVP release between aggressive and non-aggressive NAB rats (Veenema et al., 2010). In contrast to the lateral septum, local administration of synthetic AVP into the BST of aggressive NAB rats significantly reduced their aggression level without affecting anxiety-related behaviours. These findings highlight brain-region specific functions of AVP in relation to the regulation of aggressive and anxiety-related behaviours. Further microdialysis studies combined with local pharmacological or genetic manipulations are necessary in order to gain a better understanding of the region-dependent role of AVP in the regulation of intermale aggression and its interplay with anxiety. Because the extrahypothalamic AVP system is under significant influence of gonadal steroids, and testosterone, in particular, modulates AVP mRNA expression in the medial amygdala and the BST (de Vries et al., 1992), the role of sexual steroids in the control of aggression deserves closer attention.

\section{TESTOSTERONE}

Testosterone, the principal male sex steroid, has long been implicated in the regulation of aggression in both animals and humans (Dijkstra et al., 1992; Banks and Dabbs Jr., 1996; Lucion et al., 1996; Wingfield et al., 2001), although varieties between species, social status, type of aggression and type of social encounter make a simple causal relationship rather unlikely (Archer, 2006). Evidence exists for a relationship between circulating testosterone and aggression, for example during puberty, when testosterone and aggression levels simultaneously rise in most mammalian species (Koolhaas et al., 1980). Also, castration reduces aggressive behaviour, an effect which is reversible by testosterone administration (Beeman, 1947; Barfield et al., 1972; Luttge, 1972; Barr et al., 1976). The reduction in aggression after castration is accompanied by testosterone-dependent reduction in AVP immunoreactivity in the septum (de Vries et al., 1992; de Vries and Miller, 1998). Thus, testosterone effects on intermale aggression may, at least in part, be mediated by changes in the limbic AVP system. However, testosterone-independent aggressive behaviour has been described in birds in the non-breeding season (Logan and Carlin, 1991; Wingfield, 1994a,b). In humans, aggression correlates with elevated levels of plasma testosterone in adolescent men (Mattsson et al., 1980; Dabbs Jr. et al., 1991), but not in prepubertal boys (Susman et al., 1987; Constantino et al., 1993). This is confirmed in a more recent study that further demonstrates a positive relationship between testosterone and delinquency behaviour (van Bokhoven et al., 2006). Testosterone was also associated with antisocial personality in a small sample of violent men (Aromäki et al., 1999). However, others found that a combination of testosterone and low socioeconomic status was a better predictor of violence, than was testosterone alone (Dabbs Jr. and Morris, 1990; Mazur, 1995). We could recently show that basal plasma testosterone did not differ between LAB and $\mathrm{HAB}$ males, but a significant increase in plasma testosterone in response to the RI test was only found in LAB residents (Veenema et al., 2007a). Thus, the possibility exists that the acute rise in testosterone contributes to the modulation of neuronal networks regulating aggression (Delville et al., 1996).

\section{BRAIN 5-HT SYSTEM}

5-HT is synthesized in the midbrain raphe nuclei and released from projections throughout the brain, and is significantly involved in the regulation of emotionality (Lucki, 1998; Olivier and van Oorschot, 2005). Hence, 5-HT likely plays a prominent role in the pathophysiology of anxiety, depression, and aggression (Linnoila and Virkkunen, 1992; Baldwin and Rudge, 1995; Ressler and 
Nemeroff, 2000). Clinical and animal studies suggest that excessive aggression and violence are associated with reduced 5-HT function. For example, low cerebrospinal fluid levels of the 5-HT metabolite 5-hydroxyindoleacetic acid were found in patients with high levels of aggression and violent behaviour (Berman et al., 1997). Second, a direct link between a polymorphism in the microRNA target region of the 5-HT1B receptor gene and a history of aggression-related conduct-disorder behaviour was recently reported in young men (Jensen et al., 2009). This polymorphism determines the efficacy of direct interactions with the microRNA target region of the 5-HT1B receptor gene and, thus, regulates 5-HT1B receptor mRNA expression. Furthermore, variations in the 5-HT reuptake transporter gene are known to influence emotional and social behaviours (Lesch et al., 1996, 1997). For example, female rhesus monkeys carrying the short allele of the 5-HT reuptake transporter initiate more aggressive and submissive behaviour than females carrying the long variant (Jarrell et al., 2008). Several rodent studies also point towards an inhibitory role of 5-HT in intermale aggression: 5-HT acting through 5-HT1B receptors in the anterior hypothalamus reduces offensive aggression in male hamsters (Ferris, 1996; Ferris et al., 1997, 1999). In support, an increase in intermale aggression in adult male rats exposed to early life stress, i.e. maternal separation, correlates negatively with 5-HT immunoreactivity within the anterior hypothalamus (Veenema et al., 2006). Finally, abnormal forms of aggression were associated with chronically reduced 5-HT activity (Miczek et al., 2002). In contrast, other studies demonstrate that the display of aggression is associated with an acute increase in 5-HT activity (van der Vegt et al., 2003a,b; Summers et al., 2005a), indicating a possible difference in the role of 5-HT in adaptive forms of aggression, such as social dominance (high 5-HT neurotransmission) vs. excessive or abnormal forms of aggression (low 5-HT neurotransmission).

In comparing $\mathrm{LAB}$ and $\mathrm{HAB}$ rats, distinct differences in the activity of the brain 5-HT system were found. Such differences include the release of 5-HT within the hippocampus, amygdala and lateral septum in response to non-social stressors (higher in LAB rats), hippocampal 5-HT1A receptor expression (higher in $\mathrm{LAB}$ rats) and 5-HT transporter binding sites (lower in LAB rats) (Keck et al., 2005). Thus, in comparison with HAB rats, LAB rats generally seem to show higher 5-HT neurotransmission. Chronic treatment with the 5-HT reuptake inhibitor paroxetine elicited the stress-induced rise in hippocampal 5-HT only in HAB rats (Keck et al., 2005), suggesting that low 5-HT neurotransmission in HABs might contribute to their enhanced anxiety- and depression-related behaviour.

Evidence for breeding line differences in local 5-HT release during social stressors or during the display of aggression is lacking so far. Nevertheless, we have preliminary evidence for a crucial involvement of the 5-HT system in high and abnormal forms of aggression in LAB rats. Blocking postsynaptic 5-HT release by administration of a preferential 5-HT1A autoreceptor agonist selectively reduced the level of intermale aggression towards an intact intruder and decreased the number of attacks directed towards vulnerable body part of an anesthetized intruder (unpublished). This suggests that a high 5-HT neurotransmission in LABs is associated with the display of high and abnormal aggressive behaviours.

\section{BRAIN GABA SYSTEM}

Based on the findings that elevated aggression is likely to be linked to both extremely low and high levels of trait anxiety as found in $\mathrm{LAB}$ and $\mathrm{HAB}$ rats, respectively, the question arises, whether the level of intermale aggression can be altered by acute manipulation of state anxiety. Our preliminary results indicate that anxiogenic or anxiolytic substances acting on GABA receptors affect the level of aggression in $\mathrm{LAB}$ and HAB males (unpublished). $\mathrm{LAB}$ rats treated with the anxiogenic substance pentylenetetrazole - a $\mathrm{GABA}_{\mathrm{A}}$ receptor antagonist - showed higher anxiety scores on the $\mathrm{EPM}$, and this result was accompanied by a dramatic reduction in aggression and social investigation during the RI test. It has been shown that anxiogenic treatment increases neuronal activation in brain regions including the central amygdala, BST, lateral septum, and PVN that are associated with stress-, fear- and aggressionrelated behaviour (Singewald et al., 2003). Thus, treatment-induced alterations in local activity could directly affect offensive and nonoffensive social approach as seen in pentylenetetrazole-treated LAB rats. Interestingly, acute manipulation of state anxiety by anxiogenic or anxiolytic substances in NAB rats with an overall low level of aggression did not change any behavioural parameter of aggressive behaviour (unpublished). This indicates that $\mathrm{LAB}$ and $\mathrm{HAB}$ rats may be a better model of high and abnormal aggression than commercially available rats given their sensitivity to psychopharmacological manipulation.

\section{CONCLUSIONS AND FUTURE DIRECTIONS}

The striking evidence for an overlap in neuroendocrine and neurochemical systems regulating aggression as well as anxiety suggests a strong correlation between these two behaviours. Here, examples of co-morbid effects on aggression and anxiety as observed in several different rodent models are discussed, including those found after acute pharmacological interventions, exposure to early life stress, in transgenic mice, or in rodents selectively bred for extremes in emotionality. Most of the evidence to date provides support for a link between aggression and anxiety, although not always in a uni-directional manner. In this context, we could demonstrate that male $\mathrm{LAB}$ and $\mathrm{HAB}$ rats, characterized by distinct anxiety phenotypes, are a suitable model to (i) correlate parameters of aggression and anxiety-related behaviour and (ii) study underlying neuronal, neuroendocrine and neurochemical substrates. Both LAB and HAB males display elevated and abnormal forms of aggression in various tests, in which the LAB males are the most excessive. Microdialysis revealed significant differences in the release patterns of septal AVP between LAB and $\mathrm{HAB}$ rats, during the RI test, although such locally released AVP was not causally involved in regulating intermale aggression. Additionally, LAB rats generally seem to have a higher 5-HT neurotransmission compared with $\mathrm{HAB}$ rats. These and other preliminary findings lead us to conclude that $\mathrm{LAB}$ and $\mathrm{HAB}$ rats are a promising rodent model to study the link between aggression and anxiety on a behavioural, neuronal, molecular, and genetic level in more detail.

However, several animal models discussed in this review lack an obvious link between aggression and anxiety, and in other models simultaneous alterations in these behaviours were not found after acute intervention. Thus, aggression and anxiety are 
not always co-regulated, but, under some circumstances, these behaviours may come under the control of the same genes and neuroactive substances including sexual steroids, neuropeptides and neuroamines within specific brain circuitries. Such a view is in agreement with clinical findings. On the one hand, excessive and violent behaviours are seen in humans exposed to adverse early life experiences and in patients with depression- and anxietyrelated disorders, or PTSD. On the other hand, rather conflicting data exist on the effects of anxiolytic drugs on anti-social and aggressive behaviours. In future studies that focus on the neurobiological mechanisms of (co-)regulation of aggression and anxiety, epigenetic modifications need to be considered in addition to the neuronal and neuroendocrine parameters discussed above. Thus far, such studies are lacking. In contrast, a role of epigenetic modification of gene activity due to, for example, early life experiences or chronic psychosocial stress in adulthood were found to contribute to differences in adult stress coping responses (Weaver et al., 2004; Tsankova et al., 2006). Also, genetic variations, for example in the AVP V1a receptor (Young and Wang, 2004) or the 5-HT transporter (Jarrell et al., 2008), were shown to account for variations in both emotionality and complex social behaviours in animals and humans (for review see Shepard et al., 2009). Together with our findings concerning the AVP system in the $\mathrm{HAB} / \mathrm{LAB}$ rat model, a closer examination of this system in human populations with respect to co-morbid aggression and anxiety is warranted. The genetic/epigenetic predisposition of an individual is also likely to influence the behavioural effects

\section{REFERENCES}

Albers, H. E., and Bamshad, M. (1998). Role of vasopressin and oxytocin in the control of social behavior in Syrian hamsters (Mesocricetus auratus). Prog. Brain Res. 119, 395-408.

Archer,J. (2006). Testosterone and human aggression: an evaluation of the challenge hypothesis. Neurosci. Biobehav. Rev. 30, 319-345.

Aromäki, A. S., Lindman, R. E., and Eriksson, C. J. P. (1999). Testosterone, aggressiveness, and antisocial personality. Aggress. Behav. 25, 113-123.

Baldwin, D., and Rudge, S. (1995). The role of serotonin in depression and anxiety. Int. Clin. Psychopharmacol. 9(Suppl. 4), 41-45.

Bale, T. L., Contarino, A., Smith, G. W., Chan, R., Gold, L. H., Sawchenko, P. E., Koob, G. F., Vale, W. W., and Lee, K. F. (2000). Mice deficient for corticotropin-releasing hormone receptor-2 display anxiety-like behaviour and are hypersensitive to stress. Nat. Genet. 24, 410-414.

Banks, T., and Dabbs, J. M. Jr. (1996). Salivary testosterone and cortisol in a delinquent and violent urban subculture. J. Soc. Psychol. 136, 49-56.

Barfield, R. J., Busch, D. E., and Wallen, K. (1972). Gonadal influence on agonistic behavior in the male domestic rat. Horm. Behav. 3, 247-259.
Barnow, S., and Freyberger, H. J. (2003). "The family environment in early life and aggressive behavoir in adolescents and young adults," in Neurobiology of Aggression: Understanding and Preventing Violence, ed. M. Mattson (Totowa, NJ: Humana Press), 213-229.

Barr, G. A., Gibbons, J. L., and Moyer, K. E. (1976). Male-female differences and the influence of neonatal and adult testosterone on intraspecies aggression in rats. J. Comp. Physiol. Psychol. 90, 1169-1183.

Barrot, M., Wallace, D. L., Bolanos, C. A., Graham, D. L., Perrotti, L. I., Neve, R. L., Chambliss, H., Yin, J. C., and Nestler, E. J. (2005). Regulation of anxiety and initiation of sexual behavior by CREB in the nucleus accumbens. Proc. Natl. Acad. Sci. U.S.A. 102, 8357-8362.

Bartolomeos, K., Brown, D., Butchart, A., Harvey,A., Meddings, D., and Sminkey, L. (2007). Third Milestones of a Global Campaign for Violence Prevention Report. WHO Library CataloguingIn-Publication Data. Geneva: World Health Organization.

Beckham, J. C., and Moore, S. D. (2000). Interpersonal hostility and violence in Vietnam combat veterans with chronic posttraumatic stress disorder: a review of theoretical models and empirical

of neurochemicals that regulate aggression and anxiety, which may explain the discrepant outcome of anxiolytic treatment on aggressive and violent behaviour in humans.

Taking into account that complex social behaviours like aggression are more than hormone- and neuropeptide-driven events triggered by social cues, future studies are needed to reveal the (epi)genetic factors driving the switch from normal to excessive aggression and/or anxiety. Thus, genetic association studies are required to reveal gene polymorphisms in the context of high and abnormal aggression. In combination, genetic manipulations and validation of selected genes (using gene silencing techniques like antisense oligonucleotides or siRNA) or amplification of gene activity (using viral gene transfer) will likely help to reveal new insights into the regulation of normal and abnormal aggressive behaviour. The use of animal models with genetic differences in relevant neuropeptide systems underlying extremes in social and/or emotional behaviours, such as $\mathrm{LAB}$ and $\mathrm{HAB}$ rats, are a promising starting point.

\section{ACKNOWLEDGMENTS}

We thank Dr. Benjamin Rood (University of Massachusetts, Amherst, MA, USA) for the critical reading of the manuscript. Supported by BMBF (Inga D. Neumann), DFG (Inga D. Neumann; Ne465/17) and Bayerische Forschungsstiftung (Alexa H. Veenema). The experiments were approved by the Committee on Animal Health and Care of the Government of the Oberpfalz and are in accordance with the Guide for the Care and Use of Laboratory Animals by the National Institute of Health.

evidence. Aggress. Violent Behav. 5 451-466.

Beeman, E. A. (1947). The effect of male hormone on aggressive behavior in mice. Physiol. Zool. 20, 373-405.

Beiderbeck, D. I., Neumann, I. D., and Veenema, A. H. (2007). Differences in intermale aggression are accompanied by opposite vasopressin release patterns within the septum in rats bred for low and high anxiety. Eur. J. Neurosci. 26, 3597-3605.

Berman, M.E., Tracy, J. I., and Coccaro, E. F. (1997). The serotonin hypothesis of aggression revisited. Clin. Psychol. Rev. 17, 651-665.

Bester-Meredith, J. K., Young, L. J., and Marler, C. A. (1999). Species differences in paternal behavior and aggression in peromyscus and their associations with vasopressin immunoreactivity and receptors. Horm. Behav. 36, 25-38.

Blanchard, R. J., and Blanchard, D. C. (1977). Aggressive behavior in the rat. Behav. Biol. 21, 197-224.

Blanchard, R. J., and Blanchard, D. C. (1981). "The organization and modeling of animal aggression," in The Biology of Aggression, eds P. F. Brain and D. Benton (Alphen aan den Rijn: Sijthoff et Noordhoff), 529-563.

Blanchard, R. J., Takahashi, L. K., Fukunaga, K. K., and Blanchard, C. D.
(1977). Functions of the vibrissae in the defensive and aggressive behavior of the rat. Aggress. Behav. 3, 231-240.

Blanchard, R. J., Wall, P.M., and Blanchard, D. C. (2003). Problems in the study of rodent aggression. Horm. Behav. 44, 161-170.

Bond, A. J., Curran, H. V., Bruce, M. S., O'Sullivan, G., and Shine, P. (1995). Behavioural aggression in panic disorder after 8 weeks' treatment with alprazolam. J. Affect. Disord. 35, 117-123.

Bosch, O. J., Kromer, S. A., and Neumann, I. D. (2006). Prenatal stress: opposite effects on anxiety and hypothalamic expression of vasopressin and corticotropin-releasing hormone in rats selectively bred for high and low anxiety. Eur. J. Neurosci. 23, 541-551.

Bosch, O. J., Meddle, S. L., Beiderbeck, D. I., Douglas, A. J., and Neumann, I. D. (2005). Brain oxytocin correlates with maternal aggression: link to anxiety. J. Neurosci. 25, 6807-6815.

Bosch, O. J., and Neumann, I. D. (2008). Brain vasopressin is an important regulator of maternal behavior independent of dams' trait anxiety. Proc. Natl. Acad. Sci. U.S.A. 105, 17139-17144.

Bosch, O. J., and Neumann, I. D. (2010). Vasopressin released within the central amygdala promotes maternal aggression. Eur. J. Neurosci. 31, 883-891. 
Bourin, M., Petit-Demouliere, B., Dhonnchadha, B. N., and Hascoet, M. (2007). Animal models of anxiety in mice. Fundam. Clin. Pharmacol.21, 567-574.

Bunck, M., Czibere, L., Horvath, C., Graf, C., Frank, E., Kessler, M. S., Murgatroyd, C., Muller-Myhsok, B., Gonik, M., Weber, P., Putz, B., Muigg, P., Panhuysen, M., Singewald, N., Bettecken, T., Deussing, J. M., Holsboer, F., Spengler, D., and Landgraf, R. (2009). A hypomorphic vasopressin allele prevents anxietyrelated behavior. PLoS ONE 4, e5129. doi: 10.1371/journal.pone.0005129.

Cases, O., Seif, I., Grimsby, J., Gaspar, P., Chen, K., Pournin, S., Müller, U., Aguet, M., Babinet, C., Shih, J. C., and De Maeyer, E. (1995). Aggressive behavior and altered amounts of brain serotonin and norepinephrine in mice lacking MAOA. Science 268, 1763-1766.

Chen, C., Rainnie, D. G., Greene, R. W., and Tonegawa, S. (1994). Abnormal fear response and aggressive behavior in mutant mice deficient for alphacalcium-calmodulin kinase II. Science 266, 291-294.

Cherek, D. R., and Lane, S. D. (2001). Acute effects of D-fenfluramine on simultaneous measures of aggressive escape and impulsive responses of adult males with and without a history of conduct disorder. Psychopharmacology (Berl.) 157, 221-227.

Clarke, A., and File, S.E. (1983). Social and exploratory behaviour in the rat after septal administration of ORG2766 and ACTH4-10. Psychoneuroendocrinology 8, 343-350.

Coccaro, E. F., Kavoussi, R. J., Hauger, R. L., Cooper, T. B., and Ferris, C. F. (1998). Cerebrospinal fluid vasopressin levels: correlates with aggression and serotonin function in personality-disordered subjects. Arch. Gen. Psychiatry 55, 708-714.

Compaan, J. C., Buijs, R. M., Pool, C. W., De Ruiter, A. J., and Koolhaas, J. M. (1993). Differential lateral septal vasopressin innervation in aggressive and nonaggressive male mice. Brain Res. Bull. 30, 1-6.

Constantino, J. N., Grosz, D., Saenger, P., Chandler, D. W., Nandi, R., and Earls, F. J. (1993). Testosterone and aggression in children. J. Am. Acad. Child Adolesc. Psychiatry 32, 1217-1222.

Crawley, J., and Goodwin, F. K. (1980). Preliminary report of a simple animal behavior model for the anxiolytic effects of benzodiazepines. Pharmacol. Biochem. Behav. 13, 167-170.

Cryan, J. F., and Holmes, A. (2005). The ascent of mouse: advances in modelling human depression and anxiety. Nat. Rev. Drug Discov. 4, 775-790.
Dabbs, J. M. Jr., Jurkovic, G. J., and Frady, R. L. (1991). Salivary testosterone and cortisol among late adolescent male offenders. J. Abnorm. Child. Psychol. 19, 469-478.

Dabbs, J. M. Jr., and Morris, R. (1990). Testosterone, social class, and antisocial behavior in a sample of $4,462 \mathrm{men}$. Psychol. Sci. 1, 209-211.

Davidson, R. J., Putnam, K. M., and Larson, C. L. (2000). Dysfunction in the neural circuitry of emotion regulation - a possible prelude to violence. Science 289, 591-594.

deAlmeida, R.M., Ferrari,P.F.,Parmigiani, S., and Miczek, K. A. (2005). Escalated aggressive behavior: dopamine, serotonin and GABA. Eur. J. Pharmacol. 526, 51-64.

de Boer, S. F., van der Vegt, B. J., and Koolhaas, J. M. (2003). Individual variation in aggression of feral rodent strains: a standard for the genetics of aggression and violence? Behav. Genet. 33, 485-501.

de Kloet, E. R., Joels, M., and Holsboer, F. (2005). Stress and the brain: from adaptation to disease. Nat. Rev. 6, 463-475.

Delville, Y., Mansour, K. M., and Ferris, C. F. (1996). Testosterone facilitates aggression by modulating vasopressin receptors in the hypothalamus. Physiol. Behav. 60, 25-29.

deVries, G. J., and Buijs, R. M. (1983). The origin of vasopressinergic and oxytocinergic innervation of the rat brain with special reference to the lateral septum. Brain Res. 273, 307-317.

de Vries, G. J., Buijs, R. M., and Sluiter, A. A. (1984). Gonadal hormone actions on the morphology of the vasopressinergic innervation of the adult rat brain. Brain Res. 298, 141-145.

de Vries, G. J., Crenshaw, B. J., and alShamma, H. A. (1992). Gonadal steroid modulation of vasopressin pathways. Ann. N. Y. Acad. Sci. 652, 387-396.

de Vries, G. J., and Miller, M. A. (1998). Anatomy and function of extrahypothalamic vasopressin systems in the brain. Prog. Brain Res. 119, 3-20.

DeVries, A. C., Young, W. S. III, and Nelson, R. J. (1997). Reduced aggressive behaviour in mice with targeted disruption of the oxytocin gene. $J$. Neuroendocrinol. 9, 363-368.

Dijkstra, H., Tilders, F. J., Hiehle, M.A., and Smelik, P. G. (1992). Hormonal reactions to fighting in rat colonies: prolactin rises during defence, not during offence. Physiol. Behav. 51, 961-968.

DiMascio, A. (1973). The effects of benzodiazepines on aggression: reduced or increased? Psychopharmacologia 30, 95-102.

Dodge, K. A., Bates, J. E., and Pettit, G. S. (1990). Mechanisms in the cycle of violence. Science 250, 1678-1683.
Engelmann, M., Landgraf, R., and Wotjak, C.T. (2004). The hypothalamicneurohypophysial system regulates the hypothalamic-pituitary-adrenal axis under stress: an old concept revisited. Front. Neuroendocrinol. 25, 132-149.

Eronen, M., Angermeyer, M. C., and Schulze, B. (1998). The psychiatric epidemiology of violent behaviour. Soc. Psychiatry Psychiatr. Epidemiol. 33(Suppl. 1), S13-S23.

Everts, H. G., De Ruiter,A. J., and Koolhaas, J. M. (1997). Differential lateral septal vasopressin in wild-type rats: correlation with aggression. Horm. Behav. 31 , 136-144.

Fava, M. (1998). Depression with anger attacks. J. Clin. Psychiatry 59(Suppl. 18), 18-22.

Ferris, C. F. (1992). Role of vasopressin in aggressive and dominant/subordinate behaviors. Ann. N. Y. Acad. Sci. 652, 212-226.

Ferris, C. F. (1996). Serotonin diminishes aggression by suppressing the activity of the vasopressin system. Ann. N. Y. Acad. Sci. 794, 98-103.

Ferris, C. F., Lu, S. F., Messenger, T., Guillon, C. D., Heindel, N., Miller, M., Koppel, G., Bruns, F. R., and Simon, N. G. (2006). Orally active vasopressin Vla receptor antagonist, SRX251, selectively blocks aggressive behavior. Pharmacol. Biochem. Behav. $83,169-174$.

Ferris, C. F., Melloni, R. H. Jr., Koppel, G., Perry, K. W., Fuller, R. W., and Delville, Y. (1997). Vasopressin/serotonin interactions in the anterior hypothalamus control aggressive behavior in golden hamsters. J. Neurosci. 17, 4331-4340.

Ferris, C. F., and Potegal, M. (1988). Vasopressin receptor blockade in the anterior hypothalamus suppresses aggression in hamsters. Physiol. Behav. 44, 235-239.

Ferris, C. F., Stolberg, T., and Delville, Y. (1999). Serotonin regulation of aggressive behavior in male golden hamsters (Mesocricetus auratus) Behav. Neurosci. 113, 804-815.

File,S.E.,Lippa,A.S., Beer, B., and Lippa, M. T. (2004). Animal tests of anxiety. Curr. Protoc. Neurosci. Chapter 8, Unit 8.3.

Flannelly, K., and Lore, R. (1977). The influence of females upon aggression in domesticated male rats (Rattus norvegicus). Anim. Behav. 25, 654-659.

Frank, E., Salchner, P., Aldag, J. M., Salome, N., Singewald, N., Landgraf, R., and Wigger,A. (2006). Genetic predisposition to anxiety-related behavior determines coping style, neuroendocrine responses, and neuronal activation during social defeat. Behav. Neurosci. 120, 60-71.

Gariepy, J. L., Lewis, M. H., and Cairns, R.B. (1996). "Neurobiology and aggression," in Aggression and Violence:
Genetic, Neurobiological and Biosocial Perspectives, eds D. M. Stoff and R. B. Cairns (Mahwah: Lawrence Erlbaum Associates), 41-63.

Giancola, P. R., Levinson, C. A., Corman, M. D., Godlaski, A. J., Morris, D. H., Phillips, J. P., and Holt, J. C. (2009). Men and women, alcohol and aggression. Exp. Clin. Psychopharmacol. 17, 154-164.

Goodson, J. L. (2008). Nonapeptides and the evolutionary patterning of sociality. Prog. Brain Res. 170, 3-15.

Gordon, J.A., and Hen, R. (2004). Genetic approaches to the study of anxiety. Annu. Rev. Neurosci. 27, 193-222.

Grillon, C., Warner, V., Hille, J., Merikangas, K. R., Bruder, G. E., Tenke, C. E., Nomura, Y., Leite, P., and Weissman, M. M. (2005). Families at high and low risk for depression: a three-generation startle study. Biol. Psychiatry 57, 953-960.

Haller, J., Halasz, J., Makara, G. B., and Kruk, M. R. (1998). Acute effects of glucocorticoids: behavioral and pharmacological perspectives. Neurosci. Biobehav. Rev. 23, 337-344.

Haller, J., Horvath, Z., and Bakos, N. (2007). The effect of buspirone on normal and hypoarousal-driven abnormal aggression in rats. Prog. Neuropsychopharmacol. Biol. Psychiatry 31, 27-31.

Haller, J., and Kruk, M. R. (2006). Normal and abnormal aggression: human disorders and novel laboratory models. Neurosci. Biobehav. Rev. 30, 292-303.

Haller, J., Mikics, E., Halasz, J., and Toth, M. (2005). Mechanisms differentiating normal from abnormal aggression: glucocorticoids and serotonin. Eur. J. Pharmacol. 526, 89-100.

Haller, J., Millar, S., van de Schraaf, J., de Kloet, R. E., and Kruk, M. R. (2000). The active phase-related increase in corticosterone and aggression are linked. J. Neuroendocrinol. 12, 431-436.

Haller, J., van de Schraaf, J., and Kruk, M. R. (2001). Deviant forms of aggression in glucocorticoid hyporeactive rats: a model for 'pathological' aggression? J. Neuroendocrinol. 13, 102-107.

Hayden-Hixson, D. M., and Ferris, C. F. (1991). Steroid-specific regulation of agonistic responding in the anterior hypothalamus of male hamsters. Physiol. Behav. 50, 793-799.

Heim, C., and Nemeroff, C. B. (2001). The role of childhood trauma in the neurobiology of mood and anxiety disorders: preclinical and clinical studies. Biol. Psychiatry 49, 1023-1039.

Henniger, M. S., Ohl, F., Holter, S. M., Weissenbacher,P., Toschi, N., Lorscher, P., Wigger, A., Spanagel, R., and Landgraf, R. (2000). Unconditioned anxiety and social behaviour in two 
rat lines selectively bred for high and low anxiety-related behaviour. Behav. Brain Res. 111, 153-163.

Henniger, M. S., Spanagel, R., Wigger, A., Landgraf, R., and Holter, S. M. (2002). Alcohol self-administration in two rat lines selectively bred for extremes in anxiety-related behavior. Neuropsychopharmacology 26, 729-736.

Hess, J., Lesser, D., and Landgraf, R. (1992). Vasopressin and oxytocin in brain areas of rats selectively bred for differences in behavioral performance. Brain Res. 569, 106-111.

Hines, M., Allen, L. S., and Gorski, R. A. (1992). Sex differences in subregions of the medial nucleus of the amygdala and the bed nucleus of the stria terminalis of the rat. Brain Res. 579, 321-326.

Hogg, S., Hof, M., Wurbel, H., Steimer, T., de Ruiter, A., Koolhaas, J., and Sluyter, F. (2000). Behavioral profiles of genetically selected aggressive and nonaggressive male wild house mice in two anxiety tests. Behav. Genet. 30, 439-446.

Holsboer, F., Grasser, A., Friess, E., and Wiedemann, K. (1994). Steroid effects on central neurons and implications for psychiatric and neurological disorders. Ann. N. Y. Acad. Sci. 746, 345-359; discussion 359-361.

Huot, R. L., Thrivikraman, K. V., Meaney, M. J., and Plotsky, P. M. (2001). Development of adult ethanol preference and anxiety as a consequence of neonatal maternal separation in Long Evans rats and reversal with antidepressant treatment. Psychopharmacology (Berl.) 158, 366-373.

Irvin, R. W., Szot, P., Dorsa, D. M., Potegal, M., and Ferris, C. F. (1990). Vasopressin in the septal area of the golden hamster controls scent marking and grooming. Physiol. Behav. 48, 693-699.

Jarrell, H., Hoffman, J. B., Kaplan, J. R., Berga, S., Kinkead, B., and Wilson, M. E. (2008). Polymorphisms in the serotonin reuptake transporter gene modify the consequences of social status on metabolic health in female rhesus monkeys. Physiol. Behav. 93, 807-819.

Jensen, K. P., Covault, J., Conner, T. S., Tennen, H., Kranzler, H. R., and Furneaux, H. M. (2009). A common polymorphism in serotonin receptor $1 \mathrm{~B}$ mRNA moderates regulation by miR-96 and associates with aggressive human behaviors. Mol. Psychiatry 14, 381-389.

Jochum, T., Boettger, M. K., Wigger, A., Beiderbeck, D., Neumann, I. D., Landgraf, R., Sauer, H., and Bar, K. J. (2007). Decreased sensitivity to thermal pain in rats bred for high anxiety-related behaviour is attenu- ated by citalopram or diazepam treatment. Behav. Brain Res. 183, 18-24.

Keck, M. E., Sartori, S. B., Welt, T., Muller, M. B.,Ohl, F., Holsboer, F., Landgraf, R., and Singewald, N. (2005). Differences in serotonergic neurotransmission between rats displaying high or low anxiety/depression-like behaviour: effects of chronic paroxetine treatment. J. Neurochem. 92, 1170-1179.

Keck, M. E., Welt, T., Muller, M. B., Uhr, M., Ohl, F., Wigger, A., Toschi, N., Holsboer, F., and Landgraf, R. (2003). Reduction of hypothalamic vasopressinergic hyperdrive contributes to clinically relevant behavioral and neuroendocrine effects of chronic paroxetine treatment in a psychopathological rat model. Neuropsychopharmacology 28, 235-243.

Keck, M. E., Wigger, A., Welt, T., Muller, M. B., Gesing, A., Reul, J. M., Holsboer, F., Landgraf, R., and Neumann, I. D. (2002). Vasopressin mediates the response of the combined dexamethasone/CRH test in hyper-anxious rats: implications for pathogenesis of affective disorders. Neuropsychopharmacology 26, 94-105.

Kessler, R. C., McGonagle, K. A., Zhao, S., Nelson, C. B., Hughes, M., Eshleman, S., Wittchen, H. U., and Kendler, K. S. (1994). Lifetime and 12-month prevalence of DSM-III-R psychiatric disorders in the United States. Results from the National Comorbidity Survey. Arch. Gen. Psychiatry 51, 8-19.

Kim, J. J., and Haller, J. (2007). Glucocorticoid hyper- and hypofunction: stress effects on cognition and aggression. Ann. N. Y. Acad. Sci. 1113, 291-303.

Kohn, S. R., and Asnis, G. M. (2003). "Aggression in psychiatric disorders," in Neurobiology of Aggression: Understanding and Preventing Violence, ed. M. Mattson (Totowa, NJ: Humana Press Inc.).

König, M., Zimmer, A. M., Steiner, H., Holmes, P. V., Crawley, J. N., Brownstein, M. J., and Zimmer, A. (1996). Pain responses, anxiety and aggression in mice deficient in pre-proenkephalin. Nature 383, 535-538.

Koolhaas, J. M., Moor, E., Hiemstra, Y., and Bohus, B. (1991). "The testosterone-dependent vasopressinergic neurons in the medial amygdala and lateral septum: involvement in social behaviour of male rats," in Vasopressin, Vol. 208, eds S. Jard and R. Jamison (Paris/London: INSERM/ Libbey), 213-219.

Koolhaas, J. M., Schuurman, T., and Wiepkema, P. R. (1980). The organization of intraspecific agonistic behaviour in the rat. Prog. Neurobiol. $15,247-268$.

Koolhaas, J. M., van den Brink, T. H. C., Roozendaal, B., and Boorsma, F. (1990). Medial amygdala and aggressive behavior: interaction between testosterone and vasopressin. Aggress. Behav. 16, 223-229.

Kruk, M. R., Halasz, J., Meelis, W., and Haller, J. (2004). Fast positive feedback between the adrenocortical stress response and a brain mechanism involved in aggressive behavior. Behav. Neurosci. 118, 1062-1070.

Kudryavtseva, N. N., and Bondar, N. P. (2002). Anxiolytic and anxiogenic effects of diazepam in male mice with different experience of aggression. Bull. Exp. Biol. Med. 133, 372-376.

Landgraf, R. (2006). The involvement of the vasopressin system in stress-related disorders. CNS Neurol. Disord. Drug Targets 5, 167-179.

Landgraf, R., Kessler, M. S., Bunck, M., Murgatroyd, C., Spengler, D., Zimbelmann, M., Nussbaumer, M. Czibere, L., Turck, C. W., Singewald, N., Rujescu, D., and Frank, E. (2007) Candidate genes of anxiety-related behavior in $\mathrm{HAB} / \mathrm{LAB}$ rats and mice: focus on vasopressin and glyoxalase-I. Neurosci. Biobehav. Rev. 31, 89-102.

Landgraf, R., and Neumann, I. D. (2004). Vasopressin and oxytocin release within the brain: a dynamic concept of multiple and variable modes of neuropeptide communication. Front. Neuroendocrinol. 25, 150-176.

Landgraf, R., and Wigger, A. (2002). High vs low anxiety-related behavior rats: an animal model of extremes in trait anxiety. Behav. Genet. 32, 301-314.

Landgraf, R., Wigger, A., Holsboer, F., and Neumann, I. D. (1999). Hyperreactive hypothalamo-pituitaryadrenocortical axis in rats bred for high anxiety-related behaviour. $J$. Neuroendocrinol. 11, 405-407.

Lesch, K. P., Bengel, D., Heils, A., Sabol, S. Z., Greenberg, B. D., Petri, S., Benjamin, J., Muller, C. R., Hamer, D. H., and Murphy, D. L. (1996) Association of anxiety-related traits with a polymorphism in the serotonin transporter gene regulatory region. Science 274, 1527-1531.

Lesch, K. P., Meyer, J., Glatz, K., Flugge, G., Hinney, A., Hebebrand, J., Klauck, S. M., Poustka, A., Poustka, F., Bengel, D., Mossner, R., Riederer, P., and Heils, A. (1997). The 5-HT transporter gene-linked polymorphic region (5-HTTLPR) in evolutionary perspective: alternative biallelic variation in rhesus monkeys. Rapid communication. $J$. Neural Transm. 104, 1259-1266.

Levine, S., Huchton, D. M., Wiener, S. G., and Rosenfeld, P. (1991). Time course of the effect of maternal deprivation on the hypothalamic-pituitary-adrenal axis in the infant rat. Dev. Psychobiol. 24, 547-558.

Liebsch, G., Linthorst, A. C., Neumann, I. D., Reul, J. M., Holsboer, F., and Landgraf, R. (1998a). Behavioral, physiological, and neuroendocrine stress responses and differential sensitivity to diazepam in two Wistar rat lines selectively bred for highand low-anxiety-related behavior. Neuropsychopharmacology 19, 381-396.

Liebsch, G., Montkowski, A., Holsboer, F., and Landgraf, R. (1998b). Behavioural profiles of two Wistar rat lines selectively bred for high or low anxietyrelated behaviour. Behav. Brain Res. 94, 301-310.

Linnoila, V.M., and Virkkunen, M. (1992). Aggression, suicidality, and serotonin. J. Clin. Psychiatry 53(Suppl.), 46-51.

Loeber, R., and Stouthamer-Loeber, M. (1998). Development of juvenile aggression and violence. Some common misconceptions and controversies. Am. Psychol. 53, 242-259.

Logan, C. A., and Carlin, C. A. (1991). Testosterone stimulates reproductive behavior during autumn in mockingbirds (Mimus polyglottos). Horm. Behav. 25, 229-241.

Lucion, A. B., De-Almeida, R. M., and Da-Silva, R. S. (1996).Territorial aggression, body weight, carbohydrate metabolism and testosterone levels of wild rats maintained in laboratory colonies. Braz. J. Med. Biol. Res. 29, 1657-1662.

Lucki, I. (1998). The spectrum of behaviors influenced by serotonin. Biol. Psychiatry 44, 151-162.

Lukas, M., Neumann, I. D., and Veenema, A. H. (2008). Impaired social behaviour in two rat lines selectively bred for high and low anxiety-related behaviour. Soc. Behav. Neuroendocrinol. Abst. 1.19.

Luttge, W. G. (1972). Activation and inhibition of isolation induced intermale fighting behavior in castrate male CD-1 mice treated with steroidal hormones. Horm. Behav. 3, 71-81.

Malick, J. B. (1978). Selective antagonism of isolation-induced aggression in mice by diazepam following chronic administration. Pharmacol. Biochem. Behav. 8, 497-499.

Mammen, O. K., Kolko, D. J., and Pilkonis, P.A. (2002). Negative affect and parental aggression in child physical abuse. Child Abuse Negl. 26, 407-424.

Mantella, R. C., Vollmer, R. R., Li, X., and Amico, J. A. (2003). Female oxytocin-deficient mice display enhanced anxiety-related behavior. Endocrinology 144, 2291-2296.

Marino, M. D., Bourdelat-Parks, B. N., Cameron Liles, L., and Weinshenker, 
D. (2005). Genetic reduction of noradrenergic function alters social memory and reduces aggression in mice. Behav. Brain Res. 161, 197-203.

Mattsson, A., Schalling, D., Olweus, D., Low, H., and Svensson, J. (1980). Plasma testosterone, aggressive behavior, and personality dimensions in young male delinquents. J. Am. Acad. Child Psychiatry 19, 476-490.

Mazur, A. (1995). Biosocial models of deviant behavior among male army veterans. Biol. Psychol. 41, 271-293.

Mello, A. A., Mello, M. F., Carpenter, L. L., and Price, L. H. (2003). Update on stress and depression: the role of the hypothalamic-pituitary-adrenal (HPA) axis. Rev. Bras. Psiquiatr. 25, 231-238.

Miczek, K.A., Fish, E. W., and De Bold, J. F. (2003). Neurosteroids, GABAA receptors, and escalated aggressive behavior. Horm. Behav. 44, 242-257.

Miczek, K. A., Fish, E. W., De Bold, J. F., and De Almeida, R. M. (2002). Social and neural determinants of aggressive behavior: pharmacotherapeutic targets at serotonin, dopamine and gamma-aminobutyric acid systems. Psychopharmacology (Berl.) 163, 434-458.

Mikics, E., Kruk,M.R., and Haller,J. (2004). Genomic and non-genomic effects of glucocorticoids on aggressive behavior in male rats. Psychoneuroendocrinology 29, 618-635.

Millan, M. J. (2003). The neurobiology and control of anxious states. Prog. Neurobiol. 70, 83-244.

Moran, P. (1999). The epidemiology of antisocial personality disorder. Soc. Psychiatry Psychiatr. Epidemiol. 34, 231-242.

Muigg, P., Hetzenauer, A., Hauer, G., Hauschild, M., Gaburro, S., Frank, E., Landgraf, R., and Singewald, N. (2008). Impaired extinction of learned fear in rats selectively bred for high anxietyevidence of altered neuronal processing in prefrontal-amygdala pathways. Eur. J. Neurosci. 28, 2299-2309.

Müller, M. B., Zimmermann, S., Sillaber, I., Hagemeyer, T. P., Deussing, J. M., Timpl, P., Kormann, M. S., Droste, S. K., Kuhn, R., Reul, J. M., Holsboer, F., and Wurst, W. (2003). Limbic corticotropin-releasing hormone receptor 1 mediates anxiety-related behavior and hormonal adaptation to stress. Nat. Neurosci. 6, 1100-1107.

Murgatroyd, C., Wigger, A., Frank, E., Singewald, N., Bunck, M., Holsboer, F., Landgraf, R., and Spengler, D. (2004). Impaired repression at a vasopressin promoter polymorphism underlies overexpression of vasopressin in a rat model of trait anxiety. J. Neurosci. 24, 7762-7770.
Natarajan, D., de Vries, H., Saaltink, D. J., de Boer, S. F., and Koolhaas, J. M. (2009). Delineation of violence from functional aggression in mice: an ethological approach. Behav. Genet. 39, 73-90.

Naumenko, E. V., Popova, N. K., Nikulina, E. M., Dygalo, N. N., Shishkina, G. T., Borodin, P. M., and Markel, A. L. (1989). Behavior, adrenocortical activity, and brain monoamines in Norway rats selected for reduced aggressiveness towards man. Pharmacol. Biochem. Behav. 33, 85-91.

Nehrenberg, D. L., Rodriguiz, R. M., Cyr M., Zhang, X., Lauder, J. M., Gariepy, J. L., and Wetsel, W. C. (2009). An anxiety-like phenotype in mice selectively bred for aggression. Behav. Brain Res. 201, 179-191.

Nelson, R. J., Demas, G. E., Huang, P. L., Fishman, M. C., Dawson, V. L., Dawson, T. M., and Snyder, S. H. (1995). Behavioural abnormalities in male mice lacking neuronal nitric oxide synthase. Nature 378, 383-386.

Neumann, I. D., Kromer, S. A., and Bosch, O. J. (2005a). Effects of psycho-social stress during pregnancy on neuroendocrine and behavioural parameters in lactation depend on the genetically determined stress vulnerability. Psychoneuroendocrinology 30, 791-806.

Neumann, I. D., Wigger, A., Kromer, S., Frank, E., Landgraf, R., and Bosch, O. J. (2005b). Differential effects of periodic maternal separation on adult stress coping in a rat model of extremes in trait anxiety. Neuroscience 132, 867-877.

Neumann, I. D., Torner, L., and Wigger, A. (2000). Brain oxytocin: differential inhibition of neuroendocrine stress responses and anxiety-related behaviour in virgin, pregnant and lactating rats. Neuroscience 95, 567-575.

Nyberg, J. M., Vekovischeva, O., and Sandnabba, N. K. (2003). Anxiety profiles of mice selectively bred for intermale aggression. Behav. Genet. 33, 503-511.

Ogawa, S., Lubahn, D. B., Korach, K. S., and Pfaff, D. W. (1997). Behavioral effects of estrogen receptor gene disruption in male mice. Proc. Natl. Acad. Sci. U.S.A. 94, 1476-1481.

Ohayon, M. M., and Shapiro, C. M. (2000). Sleep disturbances and psychiatric disorders associated with posttraumatic stress disorder in the general population. Compr. Psychiatry 41, 469-478.

Ohl, F., Toschi, N., Wigger, A., Henniger, M. S., and Landgraf, R. (2001). Dimensions of emotionality in a rat model of innate anxiety. Behav. Neurosci. 115, 429-436.
Oliveira-Dos-Santos, A. J., Matsumoto, G., Snow, B. E., Bai, D., Houston, F P., Whishaw, I. Q., Mariathasan, S. Sasaki, T., Wakeham, A., Ohashi, P. S., Roder, J. C., Barnes, C. A. Siderovski, D. P., and Penninger, J. M. (2000). Regulation of T cell activation, anxiety, and male aggression by RGS2. Proc. Natl. Acad. Sci. U.S.A. 97 12272-12277.

Olivier, B., and van Oorschot, R. (2005). 5-HT1B receptors and aggression: a review. Eur. J. Pharmacol. 526, 207-217.

Pellow, S., Chopin, P., File, S. E., and Briley, M. (1985). Validation of open:closed arm entries in an elevated plus-maze as a measure of anxiety in the rat. $J$. Neurosci. Methods 14, 149-167.

Plotsky, P. M., and Meaney, M. J. (1993). Early, postnatal experience alters hypothalamic corticotropin-releasing factor (CRF) mRNA, median eminence $\mathrm{CRF}$ content and stress-induced release in adult rats. Brain Res. $\mathrm{Mol}$. Brain Res. 18, 195-200.

Plotsky,P.M.,Owens,M.J., and Nemeroff,C B. (1998). Psychoneuroendocrinology of depression. Hypothalamicpituitary-adrenal axis. Psychiatr. Clin. North Am. 21, 293-307.

Plyusnina, I., and Oskina, I. (1997). Behavioral and adrenocortical responses to open-field test in rats selected for reduced aggressiveness toward humans. Physiol. Behav. 61, 381-385.

Popova, N. K., Barykina, N. N., Kolpakov, D. G., and Plyusnina, I. Z. (1999). Acoustic startle response in rats genetically predisposed to different kinds of defensive behavior. Russ. J. Physiol. 85, 97-102 (in Russian).

Reber, S. O., Birkeneder, L., Veenema, A H., Obermeier, F., Falk, W., Straub, R. H., and Neumann, I. D. (2007). Adrenal insufficiency and colonic inflammation after a novel chronic psycho-social stress paradigm in mice: implications and mechanisms. Endocrinology 148, 670-682.

Ressler, K. J., and Nemeroff, C. B. (2000) Role of serotonergic and noradrenergic systems in the pathophysiology of depression and anxiety disorders. Depress. Anxiety 12(Suppl. 1), 2-19.

Rice, C. J., Sandman, C. A., Lenjavi, M. R., and Baram, T. Z. (2008). A novel mouse model for acute and longlasting consequences of early life stress. Endocrinology 149, 4892-4900.

Ring, R. H. (2005). The central vasopressinergic system: examining the opportunities for psychiatric drug development. Curr. Pharm. Des. 11 205-225.

Rodriguiz, R. M., Chu, R., Caron, M. G. and Wetsel, W. C. (2004). Aberrant responses in social interaction of dopamine transporter knockout mice. Behav. Brain Res. 148, 185-198.

Salome, N., Salchner, P., Viltart, O., Sequeira, H., Wigger, A., Landgraf, R., and Singewald, N. (2004). Neurobiological correlates of high (HAB) versus low anxiety-related behavior (LAB): differential Fos expression in $\mathrm{HAB}$ and $\mathrm{LAB}$ rats. Biol. Psychiatry 55, 715-723.

Salome, N., Viltart, O., Darnaudery, M., Salchner, P., Singewald, N., Landgraf, R., Sequeira, H., and Wigger, A. (2002). Reliability of high and low anxiety-related behaviour: influence of laboratory environment and multifactorial analysis. Behav. Brain Res. 136, 227-237.

Sandnabba, N. K. (1996). Selective breeding for isolation-induced intermale aggression in mice: associated responses and environmental influences. Behav. Genet. 26, 477-488.

Sanislow, C. A., Grilo, C. M., and McGlashan, T. H. (2000). Factor analysis of the DSM-III-R borderline personality disorder criteria in psychiatric inpatients. Am. J. Psychiatry 157, 1629-1633.

Saudou, F., Amara, D. A., Dierich, A., LeMeur, M., Ramboz, S., Segu, L., Buhot, M. C., and Hen, R. (1994). Enhanced aggressive behavior in mice lacking 5-HT1B receptor. Science 265, 1875-1878.

Scordalakes, E. M., and Rissman, E. F. (2003). Aggression in male mice lacking functional estrogen receptor alpha. Behav. Neurosci. 117, 38-45.

Shepard, K. N., Michopoulos, V., Toufexis, D. J., and Wilson, M. E. (2009). Genetic, epigenetic and environmental impact on sex differences in social behavior. Physiol. Behav. 97, 157-170.

Simon, N. G., Guillon, C., Fabio, K., Heindel, N. D., Lu, S. F., Miller, M., Ferris, C. F., Brownstein, M. J., Garripa, C., and Koppel, G. A. (2008). Vasopressin antagonists as anxiolytics and antidepressants: recent developments. Recent Pat. CNS Drug. Discov. 3, 77-93.

Singewald, N., Salchner, P., and Sharp, T. (2003). Induction of c-Fos expression in specific areas of the fear circuitry in rat forebrain by anxiogenic drugs. Biol. Psychiatry 53, 275-283.

Skodol, A. E., Gunderson, J. G., Pfohl, B., Widiger, T.A., Livesley, W. J., and Siever, L. J. (2002). The borderline diagnosis I: psychopathology, comorbidity, and personality structure. Biol. Psychiatry 51, 936-950.

Slattery, D. A., and Neumann, I. D. (2010). Chronic icv oxytocin attenuates the pathological high anxiety state of selectively bred Wistar rats. Neuropharmacology 58, 56-61. 
Sluyter, F., Arseneault, L., Moffitt, T. E., Veenema, A. H., de Boer, S., and Koolhaas, J. M. (2003). Toward an animal model for antisocial behavior: parallels between mice and humans. Behav. Genet. 33, 563-574.

Somers, J. M., Goldner, E. M., Waraich, P., and Hsu, L. (2006). Prevalence and incidence studies of anxiety disorders: a systematic review of the literature. Can. J. Psychiatry 51, 100-113.

Suchecki, D., and Palermo Neto, J. (1991). Prenatal stress and emotional response of adult offspring. Physiol. Behav. 49, 423-426.

Summers, C. H., Korzan, W. J., Lukkes, J. L., Watt, M. J., Forster, G. L., Overli, O. Hoglund, E., Larson, E. T., Ronan, P. J., Matter, J. M., Summers, T. R., Renner, K. J., and Greenberg, N. (2005a). Does serotonin influence aggression? Comparing regional activity before and during social interaction. Physiol. Biochem. Zool. 78, 679-694.

Summers, C. H., Watt, M. J., Ling, T. L., Forster, G. L., Carpenter, R. E., Korzan, W. J., Lukkes, J. L., and Overli, O. (2005b). Glucocorticoid interaction with aggression in non-mammalian vertebrates: reciprocal action. Eur. J. Pharmacol. 526, 21-35.

Summers, C. H., and Winberg, S. (2006). Interactions between the neural regulation of stress and aggression. J. Exp. Biol. 209, 4581-4589.

Surget, A., and Belzung, C. (2008). Involvement of vasopressin in affective disorders. Eur. J. Pharmacol. 583, 340-349.

Susman, E. J., Inoff-Germain, G., Nottelmann, E. D., Loriaux, D. L., Cutler, G. B. Jr., and Chrousos, G. P. (1987). Hormones, emotional dispositions, and aggressive attributes in young adolescents. Child Dev. 58, 1114-1134.

Swann, A. C. (2003). Neuroreceptor mechanisms of aggression and its treatment. J. Clin. Psychiatry 64(Suppl. 4), 26-35.

Thompson, R., Gupta, S., Miller, K., Mills, S., and Orr, S. (2004). The effects of vasopressin on human facial responses related to social communication. Psychoneuroendocrinology 29, 35-48.

Toth, M., Halasz, J., Mikics, E., Barsy, B., and Haller, J. (2008). Early social deprivation induces disturbed social communication and violent aggression in adulthood. Behav. Neurosci. $122,849-854$.

Tsankova, N. M., Berton, O., Renthal, W., Kumar,A., Neve, R. L., and Nestler, E. J. (2006). Sustained hippocampal chromatin regulation in a mouse model of depression and antidepressant action. Nat. Neurosci. 9, 519-525.

van Bokhoven, I., van Goozen, S. H., van Engeland, H., Schaal, B., Arseneault, L.,
Seguin, J. R., Assaad, J. M., Nagin, D. S., Vitaro, F., and Tremblay, R. E. (2006). Salivary testosterone and aggression, delinquency, and social dominance in a population-based longitudinal study of adolescent males. Horm. Behav. 50, 118-125.

van der Vegt, B. J., Lieuwes, N., Cremers, T. I., de Boer, S. F., and Koolhaas, J. M. (2003a). Cerebrospinal fluid monoamine and metabolite concentrations and aggression in rats. Horm. Behav. 44, 199-208.

van der Vegt, B. J., Lieuwes, N., van de Wall, E. H., Kato, K., Moya-Albiol, L., Martinez-Sanchis, S., de Boer, S. F., and Koolhaas, J. M. (2003b). Activation of serotonergic neurotransmission during the performance of aggressive behavior in rats. Behav. Neurosci. 117, 667-674.

van Oortmerssen, G. A., and Bakker, T. C. (1981).Artificial selection for short and long attack latencies in wild Mus musculus domesticus. Behav. Genet. 11, 115-126.

Veenema, A. H. (2009). Early life stress, the development of aggression and neuroendocrine and neurobiological correlates: what can we learn from animal models? Front. Neuroendocrinol. 30, 497-518.

Veenema, A. H., Beiderbeck, D. I., Lukas, M., and Neumann,I.D.(2010). Distinct correlations of vasopressin release within the lateral septum and the bed nucleus of the stria terminalis with the display of intermale aggression. Horm. Behav. [Epub ahead of print], doi: 10.1016/j.yhbeh.2010.03.006.

Veenema, A. H., Blume, A., Niederle, D., Buwalda, B., and Neumann, I. D. (2006). Effects of early life stress on adult male aggression and hypothalamic vasopressin and serotonin. Eur. J. Neurosci. 24, 1711-1720.

Veenema, A. H., Meijer, O. C., de Kloet, E. R., and Koolhaas, J. M. (2003a). Genetic selection for coping style predicts stressor susceptibility. $J$. Neuroendocrinol. 15, 256-267.

Veenema, A. H., Meijer, O. C., de Kloet, E. R., Koolhaas, J. M., and Bohus, B. G. (2003b). Differences in basal and stress-induced HPA regulation of wild house mice selected for high and low aggression. Horm. Behav. 43, 197-204.

Veenema, A. H., and Neumann, I. D. (2007). Neurobiological mechanisms of aggression and stress coping: a comparative study in mouse and rat selection lines. Brain Behav. Evol. 70, 274-285.

Veenema, A. H., and Neumann, I. D. (2008). Central vasopressin and oxytocin release: regulation of complex social behaviours. Prog. Brain Res. 170, 261-276.
Veenema, A. H., and Neumann, I. D. (2009). Maternal separation enhances offensive play-fighting, basal corticosterone and hypothalamic vasopressin mRNA expression in juvenile male rats. Psychoneuroendocrinology 34, 463-467.

Veenema, A. H., Sijtsma, B., Koolhaas, J. M., and de Kloet, E. R. (2005). The stress response to sensory contact in mice: genotype effect of the stimulus animal. Psychoneuroendocrinology 30 550-557.

Veenema, A. H., Torner, L., Blume, A. Beiderbeck, D. I., and Neumann, I. D. (2007a). Low inborn anxiety correlates with high intermale aggression: Link to ACTH response and neuronal activation of the hypothalamic paraventricular nucleus. Horm. Behav. 51, 11-19.

Veenema, A. H., Bredewold, R., and Neumann, I. D. (2007b). Opposite effects of maternal separation on intermale and maternal aggression in C57BL/6 mice: link to hypothalamic vasopressin and oxytocin immunoreactivity. Psychoneuroendocrinology 32, 437-450.

Vitiello, B., and Stoff, D. M. (1997). Subtypes of aggression and their relevance to child psychiatry. J. Am. Acad. Child Adolesc. Psychiatry 36, 307-315.

Vukhac, K. L., Sankoorikal, E. B., and Wang, Y. (2001). Dopamine D2L receptor- and age-related reduction in offensive aggression. Neuroreport 12, 1035-1038.

Weaver, I. C., Cervoni, N., Champagne, F. A., D'Alessio, A. C., Sharma, S., Seckl, J. R., Dymov, S., Szyf, M., and Meaney, M. J. (2004).Epigenetic programming by maternal behavior. Nat. Neurosci. 7, 847-854.

Wersinger, S. R., Ginns, E. I., O'Carroll, A. M., Lolait, S. J., and Young, W. S. III. (2002). Vasopressin V1b receptor knockout reduces aggressive behavior in male mice. Mol. Psychiatry 7 , 975-984.

Wiehager, S., Beiderbeck, D. I., Gruber, S. H., El-Khoury, A., Wamsteeker J., Neumann, I. D., Petersen, A., and Mathe, A.A. (2009). Increased levels of cocaine and amphetamine regulated transcript in two animal models of depression and anxiety. Neurobiol. Dis. 34, 375-380.

Wigger, A., Loerscher, P., Weissenbacher P., Holsboer, F., and Landgraf, R. (2001). Cross-fostering and crossbreeding of $\mathrm{HAB}$ and $\mathrm{LAB}$ rats: a genetic rat model of anxiety. Behav. Genet. 31, 371-382.

Wigger, A., and Neumann, I. D. (1999). Periodic maternal deprivation induces gender-dependent alterations in behavioral and neuroendocrine responses to emotional stress in adult rats. Physiol. Behav. 66, 293-302.

Wigger, A., Sanchez, M. M., Mathys, K. C., Ebner, K., Frank, E., Liu, D., Kresse, A., Neumann, I. D., Holsboer, F., Plotsky, P. M., and Landgraf, R. (2004). Alterations in central neuropeptide expression, release, and receptor binding in rats bred for high anxiety: critical role of vasopressin. Neuropsychopharmacology 29, 1-14.

Wingfield, J. C. (1994a). Control of territorial aggression in a changing environment. Psychoneuroendocrinology 19, 709-721.

Wingfield, J.C. (1994b). Regulation of territorial behavior in the sedentary song sparrow, Melospiza melodia morphna. Horm. Behav. 28, 1-15.

Wingfield, J. C., Lynn, S., and Soma, K. K. (2001). Avoiding the 'costs' of testosterone: ecological bases of hormonebehavior interactions. Brain Behav. Evol. 57, 239-251.

Winslow, J. T., Hearn, E. F., Ferguson, J., Young, L. J., Matzuk, M. M., and Insel, T. R. (2000). Infant vocalization, adult aggression, and fear behavior of an oxytocin null mutant mouse. Horm. Behav. 37, 145-155.

Wongwitdecha, N., and Marsden, C. A. (1996). Social isolation increases aggressive behaviour and alters the effects of diazepam in the rat social interaction test. Behav. Brain Res. 75, 27-32.

Yilmazer-Hanke, D. M., Wigger,A., Linke, R., Landgraf, R., and Schwegler, H. (2004). Two Wistar rat lines selectively bred for anxiety-related behavior show opposite reactions in elevated plus maze and fear-sensitized acoustic startle tests. Behav. Genet. 34, 309-318.

Young, L. J., and Wang, Z. (2004). The neurobiology of pair bonding. Nat Neurosci. 7, 1048-1054.

Conflict of Interest Statement: The authors declare that the research was conducted in the absence of any commercial or financial relationships that could be construed as a potential conflict of interest.

Received: 08 August 2009; paper pending published: 02 December 2009; accepted: 07 March 2010; published online: 30 March 2010.

Citation: Neumann ID, Veenema AH and Beiderbeck DI (2010) Aggression and anxiety: social context and neurogiological links. Front. Behav. Neurosci. 4:12. doi: 10.3389/fnbeh.2010.00012

Copyright $($ ) 2010 Neumann, Veenema and Beiderbeck. This is an open-access article subject to an exclusive license agreement between the authors and the Frontiers Research Foundation, which permits unrestricted use, distribution, and reproduction in any medium, provided the original authors and source are credited. 